\title{
Early spring mesopelagic carbon remineralization and transfer efficiency in the naturally iron-fertilized Kerguelen area
}

\author{
S. H. M. Jacquet ${ }^{1}$, F. Dehairs ${ }^{2}$, D. Lefèvre ${ }^{1}$, A. J. Cavagna ${ }^{2}$, F. Planchon ${ }^{3}$, U. Christaki ${ }^{4}$, L. Monin ${ }^{5}$, L. André ${ }^{5}$, \\ I. Closset $^{6}$, and D. Cardinal ${ }^{6}$ \\ ${ }^{1}$ Aix Marseille Université, CNRS/INSU, IRD, Mediterranean Institute of Oceanography (MIO), UM110, \\ 13288 Marseille, France \\ ${ }^{2}$ Vrije Universiteit Brussel, Analytical, Environmental \& Geo-Chemistry and Earth System Sciences, Brussels, Belgium \\ ${ }^{3}$ Laboratoire des Sciences de l'Environnement Marin (LEMAR), Université de Brest, CNRS, IRD, UMR6539, IUEM; \\ Technopôle Brest Iroise, Place Nicolas Copernic, 29280 Plouzané, France \\ ${ }^{4}$ INSU-CNRS, UMR8187 LOG, Laboratoire d'Océanologie et de Géosciences, Université du Littoral Côte d'Opale, ULCO, \\ 32 avenue Foch, 62930 Wimereux, France \\ ${ }^{5}$ Earth Sciences Department, Royal Museum for Central Africa, Leuvensesteenweg 13, Tervuren, 3080, Belgium \\ ${ }^{6}$ Sorbonne Universités (UPMC, Univ Paris 06)-CNRS-IRD-MNHN, LOCEAN Laboratory, 4 place Jussieu, \\ 75005 Paris, France
}

Correspondence to: S. H. M. Jacquet (stephanie.jacquet@mio.osupytheas.fr)

Received: 6 May 2014 - Published in Biogeosciences Discuss.: 16 June 2014

Revised: 13 February 2015 - Accepted: 23 February 2015 - Published: 17 March 2015

\begin{abstract}
We report on the zonal variability of mesopelagic particulate organic carbon remineralization and deep carbon transfer potential during the Kerguelen Ocean and Plateau compared Study 2 expedition (KEOPS 2; OctoberNovember 2011) in an area of the polar front supporting recurrent massive blooms from natural Fe fertilization. Mesopelagic carbon remineralization (MR) was assessed using the excess, non-lithogenic particulate barium $\left(\mathrm{Ba}_{\mathrm{xs}}\right)$ inventories in mesopelagic waters and compared with bacterial production (BP), surface primary production (PP) and export production (EP). Results for this early season study are compared with the results obtained during a previous study (2005; KEOPS 1) for the same area at a later stage of the phytoplankton bloom. Our results reveal the patchiness of the seasonal advancement and of the establishment of remineralization processes between the plateau (A3) and polar front sites during KEOPS 2. For the Kerguelen plateau (A3 site) we observe a similar functioning of the mesopelagic ecosystem during both seasons (spring and summer), with low and rather stable remineralization fluxes in the mesopelagic column (150-400 m). The shallow water column $(\sim 500 \mathrm{~m})$, the lateral advection, the zooplankton grazing pressure and the pulsed nature of the particulate organic carbon (POC) trans-
\end{abstract}

fer at A3 seem to drive the extent of MR processes on the plateau. For deeper stations $(>2000 \mathrm{~m}$ ) located on the margin, inside a polar front meander, as well as in the vicinity of the polar front, east of Kerguelen, remineralization in the upper $400 \mathrm{~m}$ in general represents a larger part of surface carbon export. However, when considering the upper $800 \mathrm{~m}$, in some cases, the entire flux of exported carbon is remineralized. In the polar front meander, where successive stations form a time series, two successive events of particle transfer were evidenced by remineralization rates: a first mesopelagic and deep transfer from a past bloom before the cruise, and a second transfer expanding at mesopelagic layers during the cruise. Regarding the deep carbon transfer efficiency, it appeared that above the plateau (A3 site) the mesopelagic remineralization was not a major barrier to the transfer of organic matter to the seafloor (close to $500 \mathrm{~m}$ ). There, the efficiency of carbon transfer to the bottom waters $(>400 \mathrm{~m}$ ) as assessed by PP, EP and MR fluxes comparisons reached up to $87 \%$ of the carbon exported from the upper $150 \mathrm{~m}$. In contrast, at the deeper locations, mesopelagic remineralization clearly limited the transfer of carbon to depths of $>400 \mathrm{~m}$. For sites at the margin of the plateau (station E-4W) and the polar front (station F-L), mesopelagic remineralization even exceeded 
upper $150 \mathrm{~m}$ export, resulting in a zero transfer efficiency to depths $>800 \mathrm{~m}$. In the polar front meander (time series), the capacity of the meander to transfer carbon to depth $>800 \mathrm{~m}$ was highly variable ( 0 to $73 \%$ ). The highest carbon transfer efficiencies in the meander are furthermore coupled to intense and complete deep ( $>800 \mathrm{~m}$ ) remineralization, resulting again in a near-zero, deep $(>2000 \mathrm{~m})$ carbon sequestration efficiency there.

\section{Introduction}

While numerous artificial (Boyd et al., 2000, 2004; Gervais et al., 2002; Buesseler et al., 2004, 2005; de Baar et al., 2005; Hoffmann et al., 2006; Boyd et al., 2012; Smetacek et al., 2012) and natural (Blain et al., 2007; Pollard et al., 2009; Zhou et al., 2010, 2013) ocean iron-fertilization experiments in the Southern Ocean have demonstrated the role of iron in enhancing the phytoplankton biomass and production in high-nutrient low-chlorophyll (HNLC) regions, determining to what extent fertilization could modify the transfer of particulate organic carbon (POC) to the deep ocean is far from being comprehensively achieved (Lampitt et al., 2008; Morris and Charette, 2013; Le Moigne et al., 2014; Robinson et al., 2014). This is partly due to the short term over which the observations were made, precluding extrapolation to longer timescales. Moreover, when assessing whether Fe-supply could induce vertical POC transfer, the magnitude of the export from the surface is not the only important parameter to take into account. Indeed, POC fate in the mesopelagic zone (defined as the 100-1000 $\mathrm{m}$ depth layer) is often largely overlooked although these depth layers are responsible for the remineralization of most of the POC exported from the surface layer (Martin et al., 1987; Longhurst, 1990; Lampitt and Antia, 1997; François et al., 2002; Buesseler et al., 2007b; Buesseler and Boyd, 2009). Only few studies have considered mesopelagic carbon $(C)$ remineralization rates (Buesseler et al., 2007a; Jacquet et al., 2008a, b, 2011a, b; Salter et al., 2007) to estimate the response of deep POC export to fertilization. Assessing mesopelagic $\mathrm{C}$ remineralization is pivotal for evaluating remineralization length scale as well as the timescale of the $\mathrm{C}$ storage in the deep ocean. Indeed the typical depth of the main thermocline, $1000 \mathrm{~m}$ (IPCC, WG1, 2007 , chapter 5) is often referred to as the horizon, clearly removed from the surface ocean and atmosphere (Passow and Carlson, 2012). Overall, assessing mesopelagic C remineralization will allow one to better quantify the ocean's biological carbon pump and its efficiency in the global $\mathrm{C}$ cycle which holds large uncertainty and is currently under debate (e.g. from $5 \mathrm{Gt} \mathrm{yr}^{-1}$ in Henson et al., 2011 to $21 \mathrm{Gt} \mathrm{C} \mathrm{yr}^{-1}$ in Laws et al., 2000 and $13 \mathrm{Gt} \mathrm{yr}^{-1}$ in the IPCC WG1 report (2013, chapter 6)).

The present work aims at understanding the impact of a natural iron-induced bloom on the mesopelagic POC rem- ineralization and zonal variability in the Kerguelen area (Southern Ocean). Here, C remineralization was assessed from particulate biogenic $\mathrm{Ba}$ (hereafter called excess $\mathrm{Ba}$ or $\mathrm{Ba}_{\mathrm{xs}}$; mainly forms as barite $\mathrm{BaSO}_{4}$ crystals) contents in the mesopelagic water column. The link between barite and $\mathrm{C}$ remineralization depends on the fact that this mineral precipitates in oversaturated micro-environments (biogenic aggregates) during the process of prokaryotic degradation of sinking POC (Dehairs et al., 1980, 1992, 1997, 2008; Stroobants et al., 1991, Cardinal et al., 2001, 2005; Jacquet et al., 2007, 2008b, 2011a; Planchon et al., 2013; Sternberg et al., 2007, 2008a, 2008b). Once the aggregates have been remineralized, barites are released and spread through the mesopelagic layer. Overall, earlier work highlights the fact that suspended barite in mesopelagic waters builds up over the growing season and reflects past remineralization activity integrated over several days to weeks (Dehairs et al., 1997; Cardinal et al., 2005; Jacquet et al., 2007, 2008b). An algorithm linking mesopelagic $\mathrm{Ba}_{\mathrm{xs}}$ contents to oxygen consumption (Shopova et al., 1995; Dehairs et al., 1997) allowed remineralization of POC fluxes to be estimated for the mesopelagic layer. Combined with surface $\mathrm{C}$ production and export estimates, mesopelagic $\mathrm{Ba}_{\mathrm{xs}}$ also highlights the deep carbon transfer efficiency of the system. From earlier studies, the efficiency of $\mathrm{C}$ transfer through the mesopelagic layer was reported to increase under artificially induced (EIFEX; Strass et al., 2005; Smetacek et al., 2012) and natural (KEOPS; Blain et al., 2007) Fe-replete conditions (Jacquet et al., 2008a, b; Savoye et al., 2008) compared to Fe-limited, non-bloom HNLC reference stations in the Southern Ocean. In contrast, $\mathrm{C}$ transfer efficiency through the mesopelagic layer was reported to be lower in natural Fe-replete locations during the SAZ-Sense (Sub-Antarctic Zone Sensitivity to Environmental Change) cruise off Tasmania (Jacquet et al., 2011a, b). Differences in plankton community structure and composition (e.g. diatoms vs. flagellates, type of diatoms) were suggested as possible causes of such discrepancies in $\mathrm{C}$ transfer efficiency through the mesopelagic layer (Jacquet et al., 2008a, 2011a, b). Also, differences in integration timescales for the processes that control the carbon fluxes in artificially vs. naturally Fe fertilized systems may yield an incomplete picture of the $\mathrm{C}$ transfer potential and lead to misleading conclusions.

Here, we examine changes in mesopelagic POC remineralization during the early spring (October-November 2011) KEOPS 2 expedition to the naturally iron-fertilized area east of Kerguelen Islands. The hydrographic structure of the Kerguelen area generates contrasted environments that are differently impacted by iron availability and mesoscale activity. The specific objectives of the present work are to assess the zonal variability of mesopelagic $\mathrm{C}$ remineralization and deep $\mathrm{C}$ transfer potential, and to identify possible causes of this variability. The same area was visited earlier in 2005 during summer at a late stage of the bloom (KEOPS 1; January-February 2005), offering a unique opportunity to estimate the main carbon fluxes over most of the growth sea- 

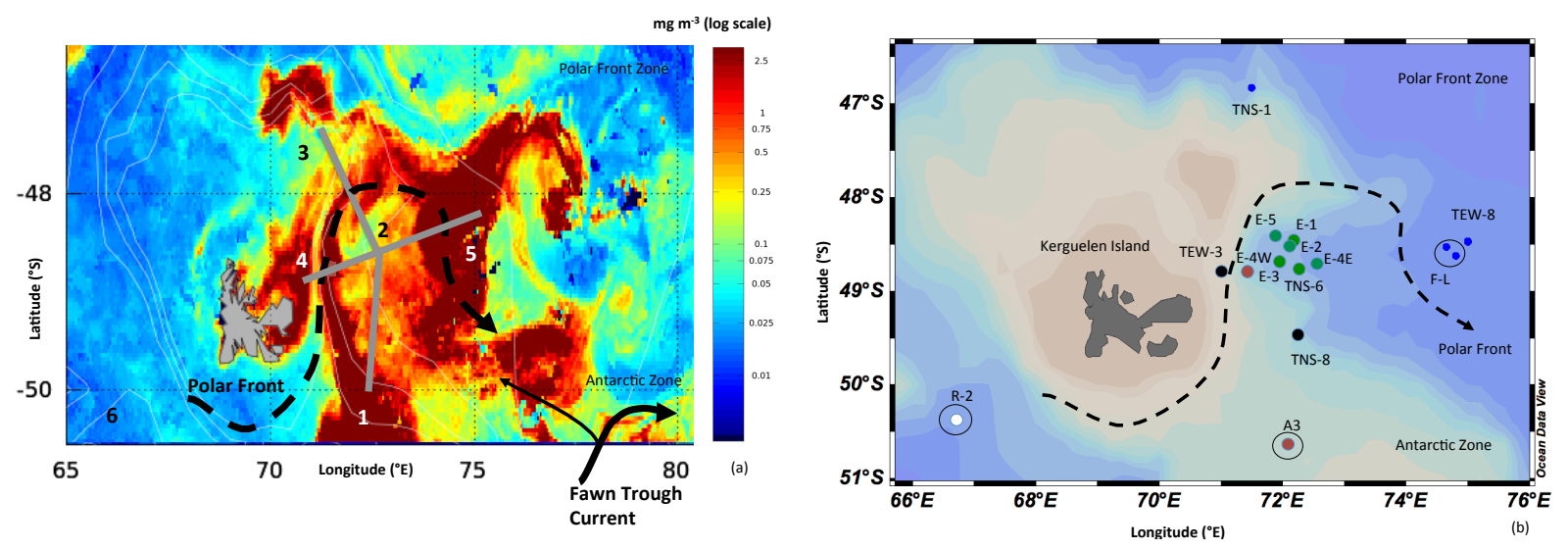

Figure 1. (a) Kerguelen Island area in the Southern Ocean with KEOPS 2 sampling zones and MODIS chlorophyll concentrations (mg $\mathrm{m}^{-3}$ ) (Chl $a$ map from 11 November 2011, courtesy of F. d'Ovidio) superimposed. 1 refers to station A3; 2 to stations E; 3 to the south-north transect; 4 to the west-east transect; 5 to station F-L and 6 to reference station R-2; (b) Corresponding stations location. Colours indicate stations with similar $\theta-S$ and $\mathrm{Chl} a$ characteristics.

son. Mesopelagic $\mathrm{C}$ remineralization estimates are compared to particle and biological parameters as reported in other papers included in this issue (Cavagna et al., 2014; Christaki et al., 2014; Dehairs et al., 2014; Lasbleiz et al., 2014; Laurenceau-Cornec et al., 2015; Planchon et al., 2014; van der Merve et al., 2015) and in Blain et al. (2007), Christaki et al. (2008), Jacquet et al. (2008a), Park et al. (2008) and Savoye et al. (2008).

\section{Experiment and methods}

\subsection{Study area}

The KEOPS 2 (Kerguelen Ocean and Plateau compared Study) cruise was conducted in austral spring at the onset of the bloom from 10 October to 20 November aboard the R/V Marion Dufresne (TAAF/IPEV). The KEOPS 2 expedition studied the Kerguelen Plateau area (Indian sector of the Southern Ocean) which is characterized by the passage of the polar front (PF), as illustrated in Fig. 1a. The Kerguelen Plateau is surrounded by the Antarctic Circumpolar Current (ACC) whose main branch circulates to the north of the plateau (Park et al., 2008). A second branch of the ACC circulates to the south of Kerguelen Islands to later join a branch of the Fawn Trough Current (FTC). The FTC has a main northeast direction, but a minor branch splits away northwestward to join the eastern side of the Kerguelen Plateau (Park et al., 2008; Fig. 1a). These particular hydrographic features generate a mosaic of recurrent massive bloom patterns in the northeastern part of the plateau, and the possible sources and mechanisms for fertilization were investigated during ANTARES 3 (1995; Blain et al., 2001) and the KEOPS 1 cruise (January-February 2005, late summer conditions; Blain et al., 2007, 2008). During KEOPS 2 the evolution of $\mathrm{Chl} a$ data based on multi-satellite imagery of the study area revealed the presence of different Chl $a$ rich plumes (D'Ovidio et al., 2015) (Fig. 1a; e.g. Chl $a$ map from 11 November 2011). Stations were sampled in distinct zones covering these different bloom patterns (Fig. 1a) (corresponding stations are reported in Fig. 1b): (a) on the shallow plateau (station A3; see 1 in Fig. 1a). Note that station A3 coincides with a site studied during the KEOPS 1 cruise, and that it was sampled twice over a 27-day period; (b) in a meander formed by a quasi-permanent retroflection of the polar front $(\mathrm{PF})$ and topographically steered by the eastern escarpment (Gallieni Spur) of the Kerguelen Plateau (mainly stations E, sampled as a quasi-Lagrangian temporal series) (see 2 in Fig. 1a); (c) along a north-south transect (referred to as TNS stations; see 3, grey line in Fig. 1a) and a eastwest transect (referred to as TEW stations; see 4, grey line in Fig. 1a), both crossing the PF; and (d) in the polar front zone (PFZ) in the vicinity (east) of the PF (station F-L; see 5 in Fig. 1a). Furthermore we also sampled a reference HNLC, non-bloom, non-Fe-fertilized station southwest of the plateau (station R-2; see 6 in Fig. 1a). Station locations are given in Table 1.

Detailed descriptions of the complex physical structure of the area, circulation, water masses and fronts are given in Park et al. (2014). Briefly, the main hydrodynamic features observed during the cruise are the following (see $\theta-S$ diagram, Fig. 2a): (1) north of the PF, stations in the PFZ (TNS-1, TEW-8 and F-L) present Antarctic Surface Waters (AASW; $\theta \simeq 4{ }^{\circ} \mathrm{C}$ and density $<27$ ); $\theta-S$ characteristics between 150 to $400 \mathrm{~m}$ at station F-L (and to a lesser extent at station TNS-1) reveal the presence of interleaving with waters from northern (subantarctic) origin, centred between the 27.2 and $27.5 \mathrm{~kg} \mathrm{~m}^{-3}$ density curves, where Antarctic Intermediate Waters (AAIW) are usually found. This contrasts with the conditions at station TEW-8, where there is no evidence of interleaving; (2) stations south of 

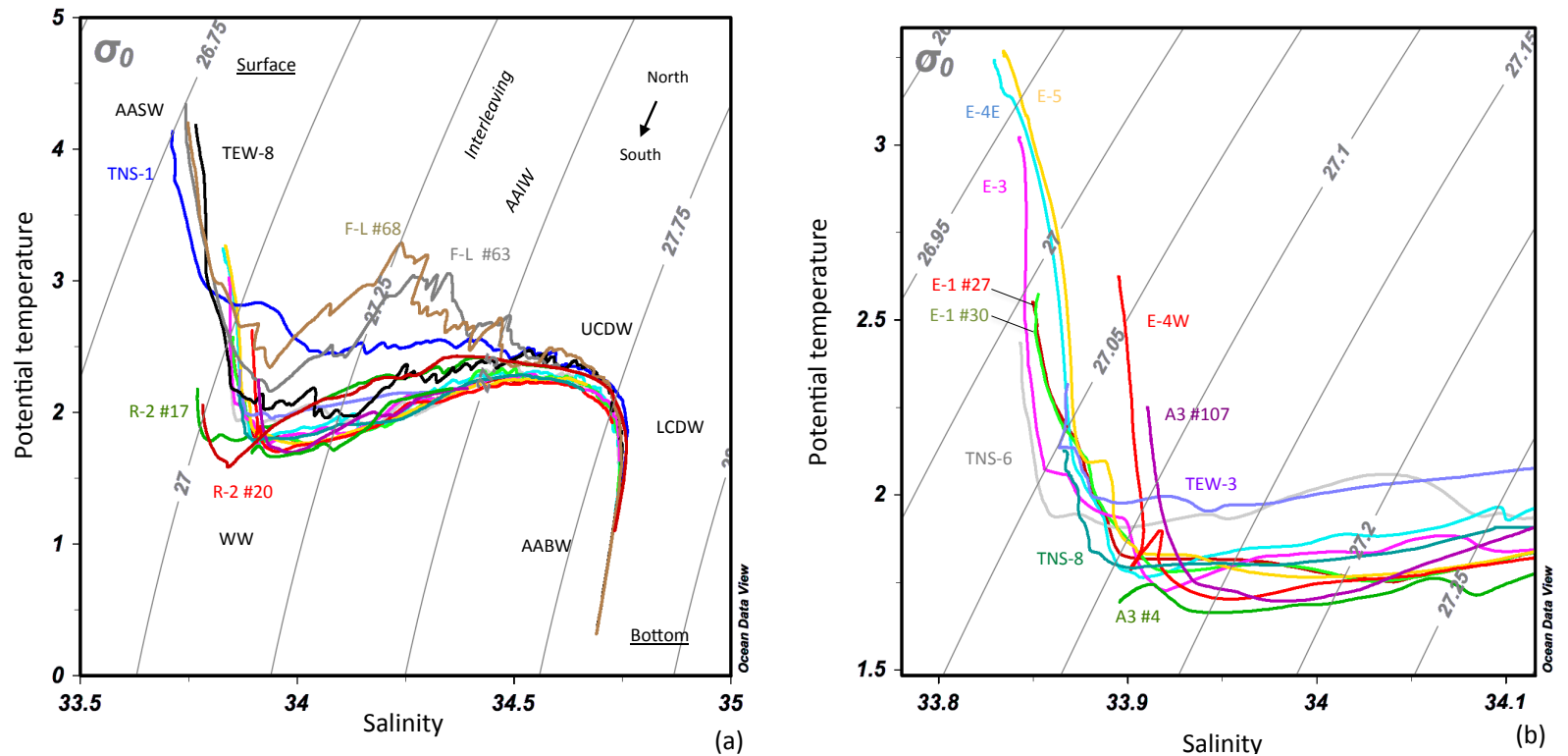

Figure 2. (a) Potential temperature $\theta$-salinity $S$ plots and isopycnals for KEOPS 2 profiles, (b) Focus on the upper $200 \mathrm{~m}$ water column. AASW: Antarctic Surface Waters, AAIW: Antarctic Intermediate Waters, WW: winter waters, UCDW and LCDW: Upper and Lower Circumpolar Deep Water, AABW: Antarctic Bottom Water. Graph constructed using Ocean Data View (Schlitzer, 2002; Ocean Data View; http://www.awi-bremerhaven.de/GEO/ODV).

Table 1. Station locations, cast numbers and bottom depths during KEOPS 2. Depth-weighted average (DWA) values of mesopelagic $\mathrm{Ba}_{\mathrm{xs}}{ }^{-}$ (pM) and $\mathrm{Ba}_{\mathrm{xs}}$-based mesopelagic POC remineralization (MR; $\mathrm{mg} \mathrm{Cm}^{-2} \mathrm{day}^{-1}$ ) integrated between $150-400$ and $150-800 \mathrm{~m}$ depths. See text for further information on calculation.

\begin{tabular}{|c|c|c|c|c|c|c|c|c|c|c|c|}
\hline Station & $\begin{array}{c}\text { CTD } \\
\text { cast no. }\end{array}$ & $\begin{array}{l}\text { Long } \\
\left({ }^{\circ} \mathrm{E}\right)\end{array}$ & $\begin{array}{l}\text { Lat } \\
\left({ }^{\circ} \mathrm{S}\right)\end{array}$ & $\begin{array}{c}\text { Date of } \\
\text { sampling }\end{array}$ & $\begin{array}{c}\text { Seafloor } \\
{[\mathrm{m}]}\end{array}$ & $\begin{array}{c}\text { DWA } \\
\text { Baxs }[\mathrm{pM}] \\
150-400 \mathrm{~m}\end{array}$ & $\begin{array}{c}\text { DWA } \\
\text { Baxs }[\mathrm{pM}] \\
150-800 \mathrm{~m}\end{array}$ & $\begin{array}{c}\text { MR } \\
150-400 \mathrm{~m} \\
{\left[\mathrm{mg} \mathrm{Cm}^{-2} \text { day }^{-1}\right]}\end{array}$ & $\begin{array}{c}\text { MR Std. } \\
\text { Uncertainty } \\
\%\end{array}$ & $\begin{array}{c}\text { MR } \\
150-800 \mathrm{~m} \\
{\left[\mathrm{mg} \mathrm{C} \mathrm{m}^{-2} \text { day }^{-1}\right]}\end{array}$ & $\begin{array}{c}\text { MR Std. } \\
\text { Uncertainty } \\
\%\end{array}$ \\
\hline \multicolumn{12}{|l|}{ Plateau } \\
\hline A3-1 & $4^{\mathrm{a}}$ & 72.080 & 50.629 & 20 Oct 2011 & 530 & 316 & - & 14 & 4 & - & - \\
\hline A3-2 & $107^{\mathrm{a}}$ & 72.056 & 50.624 & 16 Nov 2011 & 527 & 267 & - & 11 & 5 & - & - \\
\hline TEW-3 & 38 & 71.018 & 48.799 & 31 Oct 2011 & 560 & 324 & - & 28 & 8 & - & - \\
\hline \multicolumn{12}{|l|}{ Meander time series } \\
\hline TNS-6 & 10 & 72.277 & 48.779 & 22 Oct 2011 & 1885 & 427 & 389 & 31 & 7 & 69 & 17 \\
\hline E-1 & $27 / 30$ & 72.187 & 48.458 & 29,30 Oct 2011 & 2056 & 387 & 325 & 26 & 6 & 48 & 14 \\
\hline E-2 & 43 & 72.077 & 48.523 & 1 Nov 2011 & 2003 & 301 & 309 & 15 & 5 & 42 & 13 \\
\hline E-3 & $50 / 55$ & 71.967 & 48.702 & 3, 4 Nov 2011 & 1915 & 258 & 286 & 10 & 4 & 35 & 12 \\
\hline E-4E & $94 / 97$ & 72.563 & 48.715 & 13, 14 Nov 2011 & 2210 & 395 & 357 & 27 & 7 & 58 & 15 \\
\hline E-5 & $113 / 114$ & 71.900 & 48.412 & 18 Nov 2011 & 1920 & 402 & 380 & 28 & 7 & 66 & 17 \\
\hline \multicolumn{12}{|l|}{ Polar front zone } \\
\hline TNS-1 & 15 & 71.501 & 46.833 & 23 Oct 2011 & 2280 & 350 & 315 & 22 & 6 & 45 & 14 \\
\hline TEW-8 & 47 & 74.999 & 48.471 & 2 Nov 2011 & 2786 & 199 & 240 & 2 & 4 & 20 & 11 \\
\hline F-L & $63 / 68$ & 74.659 & 48.532 & 6, 7 Nov 2011 & 2695 & 345 & 328 & 21 & 6 & 49 & 14 \\
\hline \multicolumn{12}{|l|}{ Polar front } \\
\hline E-4W & $81 / 87$ & 71.425 & 48.765 & 11, 12 Nov 2011 & 1384 & 468 & 411 & 36 & 8 & 76 & 18 \\
\hline \multicolumn{12}{|l|}{ Antarctic zone } \\
\hline R-2 (reference site) & $17 / 20$ & 66.717 & 50.359 & 25,26 Oct 2011 & 2300 & 572 & 456 & 50 & 10 & 91 & 20 \\
\hline TNS-8 & 8 & 72.240 & 49.463 & 21 Oct 2011 & 1030 & 473 & 358 & 37 & 8 & 59 & 15 \\
\hline
\end{tabular}

${ }^{a}$ Station A3 (CTD no. 4 and 107); integration up to 354 and $405 \mathrm{~m}$.

the PF exhibit subsurface temperature minima characteristic of winter waters (WW); below the WW, three water masses can be identified, namely: the Upper (temperature maximum) and Lower (salinity maximum) Circumpo- lar Deep Water (UCDW and LCDW), and the Antarctic Bottom Water $(\mathrm{AABW})$. These water masses are present roughly in the following depth intervals: $700 \mathrm{~m}<\mathrm{UCDW}<1500 \mathrm{~m}$; $1500 \mathrm{~m}<\mathrm{LCDW}<2500 \mathrm{~m}$; AABW $>2500 \mathrm{~m}$. 
Based on the $\theta-S$ characteristics (Fig. 2a, b) and surface phytoplankton biomasses, we can schematically group the stations as follows. The R-2 HNLC reference station (white dot in Fig. 1b) is characterized by a very low biomass (with low iron contents; Quéroué et al., 2015). Stations TEW-3 and TNS-8 (black dots) are characterized by low to moderate biomass and Fe contents. Stations A3 and E-4W (red dots; south of the PF) as well as stations TNS-1, F-L and TEW-8 (blue dots; north of the PF) are characterized by high biomass and iron contents. Stations in the core of the PF meander (green dots; stations TNS-6, E-1, E-2, E-3, E-4E and E-5 considered as a temporal series) are characterized by moderate biomass and iron contents.

\subsection{Sampling and analyses}

Twenty-two CTD (conductivity, temperature, and depth) casts (surface to 500-2000 m) were sampled for particulate barium (Table 1) using a CTD rosette equipped with twenty-two $12 \mathrm{~L}$ Niskin bottles. Deep particulate Ba profiles ( $>1000 \mathrm{~m}$ ) were not systematically obtained from the same CTD cast, but from successive casts sampled closely in time and space and having similar $\theta-S$ data profiles. In the following, we use both the station and CTD numbers to refer to stations.

Four to $7 \mathrm{~L}$ of seawater were filtered onto $47 \mathrm{~mm}$ polycarbonate membranes $(0.4 \mu \mathrm{m}$ porosity) under slight overpressure supplied by filtered air $(0.4 \mu \mathrm{m})$. The filters were rinsed with Milli-Q grade water $(<5 \mathrm{~mL})$ to remove sea salt, dried (at $50{ }^{\circ} \mathrm{C}$ ) and stored in Petri dishes for later analysis. In the laboratory, we performed a total digestion of samples using a tri-acid $\left(0.5 \mathrm{~mL} \mathrm{HF} / 1.5 \mathrm{~mL} \mathrm{HCl} / 1 \mathrm{~mL} \mathrm{HNO}_{3}\right.$; all Suprapur grade) mixture in closed Teflon beakers overnight at $90^{\circ} \mathrm{C}$ in a clean pressurized room. After evaporating until nearly dry, samples were re-dissolved into around $13 \mathrm{~mL}$ of $2 \% \mathrm{HNO}_{3}$. The solutions were analysed for $\mathrm{Ba}$ and other major and minor elements using a ICP-QMS (inductively coupled plasma quadrupole mass spectrometer; $\mathrm{X}$ Series 2 Thermo Fisher) equipped with collision cell technology (CCT). To correct instrumental drift and matrix effects, internal standards and matrix-matched calibrations were used. We analysed several certified reference materials which consisted of dilute aciddigested rocks (BHVO-1, JB-3 and JGb-1), natural riverine water (SLRS-5) and multi-element artificial solutions for these external calibrations. Based on analyses of these external standards, accuracy and reproducibility are both better than $\pm 5 \%$. For more details on sample processing and analysis we refer to Cardinal et al. (2001). Among all elements analysed, we were particularly interested in $\mathrm{Ba}$ and Al. The presence of sea salt was checked by analysing $\mathrm{Na}$ and the sea-salt particulate $\mathrm{Ba}$ contribution was found to be negligible. Average detection limits equal $0.6 \mathrm{nM}$ for $\mathrm{Al}$ and 3 pM for Ba. Detection limits were calculated as 3 times the standard deviation of the blank measured on board and then normalized to an average dilution factor of 385 , i.e. particles from around $5 \mathrm{~L}$ of Milli-Q water, dissolved in a final volume of $13 \mathrm{~mL}$ as for the samples. Biogenic barium (hereafter called excess $\mathrm{Ba}$ or $\mathrm{Ba}_{\mathrm{xs}}$ ) was calculated as the difference between total particulate $\mathrm{Ba}$ and lithogenic $\mathrm{Ba}$ using $\mathrm{Al}$ as the lithogenic reference element (Dymond et al., 1992; Taylor and McLennan, 1985). At most sites and depths, the biogenic $\mathrm{Ba}_{\mathrm{xs}}$ represented $>95 \%$ of total particulate $\mathrm{Ba}$. Lithogenic $\mathrm{Ba}$ reached up to $20 \%$ of total particulate $\mathrm{Ba}$ at some depths in the upper $80-100 \mathrm{~m}$ mainly at station R-2 and stations north of the polar front (i.e. TEW-8, F-L and TNS-1). The standard uncertainty (Ellison et al., 2000) of $\mathrm{Ba}_{\mathrm{xs}}$ data ranges between 5 and $5.5 \% . \mathrm{Ba}_{\mathrm{xs}}$ and $\mathrm{Al}$ data are reported in Appendix A.

\section{3 $\mathrm{O}_{2}$ consumption and $\mathrm{POC}$ remineralization}

The rate of oxygen consumption and particulate organic carbon remineralization rate in the mesopelagic layer (later referred to as MR) can be estimated using an algorithm relating mesopelagic $\mathrm{Ba}_{\mathrm{xs}}$ contents and oxygen consumption based on earlier observations in the Southern Ocean (Shopova et al., 1995; Dehairs et al., 1997, 2008). The detailed calculations are described in Jacquet et al. (2008a, 2011a). Briefly, we use the following equations:

$J_{\mathrm{O}-2}=\left(\mathrm{Ba}_{\mathrm{xs}}-\mathrm{Ba}_{\text {residual }}\right) / 17450$,
$\mathrm{C}_{\text {respired }}=Z \times J_{\mathrm{O}_{2}} \times \mathrm{RR}$,

where $J_{\mathrm{O}_{2}}$ is the $\mathrm{O}_{2}$ consumption $\left(\mu \mathrm{mol} \mathrm{L} \mathrm{L}^{-1}\right.$ day $\left.{ }^{-1}\right)$ and $\mathrm{C}_{\text {respired }}$ is the mineralization rate of organic carbon (in mmol $\mathrm{C} \mathrm{m}^{-2}$ day $^{-1}$; MR); $\mathrm{Ba}_{\mathrm{xs}}$ is the depth-weighted average (DWA) $\mathrm{Ba}_{\mathrm{xs}}$ value, i.e. the $\mathrm{Ba}_{\mathrm{xs}}$ inventory divided by the depth layer considered $\mathrm{Z}, \mathrm{Ba}_{\text {residual }}$ is the residual $\mathrm{Ba}_{\mathrm{xs}}$ signal (or $\mathrm{Ba}_{\mathrm{xs}}$ background) at zero oxygen consumption and $\mathrm{RR}$ is the Redfield C / $\mathrm{O}_{2}$ molar ratio (127/175; Broecker et al., 1985). DWA $\mathrm{Ba}_{\mathrm{xs}}$ values were calculated for both layers at 150 to $400 \mathrm{~m}$ (plateau and deep stations) and 150 to $800 \mathrm{~m}$ (deep stations only; see details further below). The residual $\mathrm{Ba}_{\mathrm{xs}}$ is considered as "preformed" $\mathrm{Ba}_{\mathrm{xs}}$, left over after partial dissolution and sedimentation of $\mathrm{Ba}_{\mathrm{xs}}$ produced during a previous phytoplankton growth event. In $\mathrm{BaSO}_{4}$, saturated waters, such as the ones filling the whole ACC water column (Monnin et al., 1999), this background $\mathrm{Ba}_{\mathrm{xs}}$ value was considered to reach 180 to $200 \mathrm{pM}$, which is rather characteristic for the deep ocean (> $1000 \mathrm{~m}$ ) (see Dehairs et al., 1997; Jacquet et al., 2008a, 2011). In the present study we used a $\mathrm{Ba}_{\mathrm{xs}}$ background of $180 \mathrm{pM}$.

We take the opportunity here to also compare $\mathrm{O}_{2}$ consumption rates for the KEOPS 1 expedition (D. Lefèvre, unpublished data) with KEOPS $1 \mathrm{Ba}_{\mathrm{xs}}$ data published earlier (Jacquet et al., 2008a). No such $\mathrm{O}_{2}$ consumption data are available for KEOPS 2. During KEOPS 1, dark community respiration (DCR) was estimated from changes in the dissolved oxygen concentration over $72 \mathrm{~h}$ incubations. Discrete samples were collected at three depths in the mesopelagic 
zone from Niskin bottles and placed into $125 \mathrm{~cm}^{3}$ borosilicate glass bottles according to the WOCE (World Ocean Circulation Experiment) procedure, and oxygen concentration was determined by Winkler titrations using a photometric endpoint detector (Williams and Jenkinson, 1982). By integrating DCR data with the water column, we estimated the rate of oxygen consumption (referred to as $\mathrm{JO}_{2}-\mathrm{W}$ ). We compared $\mathrm{JO}_{2}-\mathrm{W}$ obtained from incubated oxygen samples with the rate of oxygen consumption based on KEOPS 1 mesopelagic $\mathrm{Ba}_{\mathrm{xs}}$ contents (Eq. 1; later referred to as $\mathrm{JO}_{2}$ $\mathrm{Ba})$. Dissolved oxygen was measured three times at station A3 (same location as during KEOPS2) over a 19-day period (A3 CTD no. 32, 74 and 119). Dissolved oxygen was also measured at station C11, located off-shelf in less productive HNLC waters $\left(51.65^{\circ} \mathrm{S}, 78.00^{\circ} \mathrm{E}\right.$; not shown in Fig. 1) and was sampled two times over a 10-day period (C11 CTD no. 42 and 83). Figure 3 compares $\mathrm{JO}_{2}-\mathrm{W}$ and $\mathrm{JO}_{2}-\mathrm{Ba}$ for repeat stations A3 (no. 32, 74 and 119) and $\mathrm{C} 11$ (no. 42 and 83) (integration between $150-300 \mathrm{~m}$ ). $\mathrm{JO}_{2}-\mathrm{W}$ rates range from 0.082 to $0.208 \mathrm{mmol} \mathrm{m}^{-2} \mathrm{day}^{-1}$ at station $\mathrm{A} 3$ and from 0.292 to $0.528 \mathrm{mmol} \mathrm{m}^{-2}$ day $^{-1}$ at station $\mathrm{C} 11$. Although $\mathrm{JO}_{2}-\mathrm{Ba}$ rates (from 0.846 to $1.555 \mathrm{mmol} \mathrm{m}^{-2} \mathrm{day}^{-1}$ ) are slightly higher than $\mathrm{JO}_{2}-\mathrm{W}, \mathrm{JO}_{2}$ rates are of the same order of magnitude and present the same trend. We observed a significant positive correlation between the $\mathrm{JO}_{2}$ rates $\left(R^{2}=0.90\right.$; $p<0.01$ ), with a slope of 0.64 . The difference in oxygen consumption rates can be explained by the integration time of both methods (a few hours for the incubations vs. few days to weeks for $\mathrm{Ba}_{\mathrm{xs}}$ ) and by the fact that KEOPS 1 occurred at the decline of the bloom (late summer; low organic substrates), which would explain the lower $\mathrm{JO}_{2}$ rates as estimated by the incubation method.

Overall, these results highlight the need for further constraining spatial and temporal variability of deep ocean oxygen utilization via a combination of direct rate measurements and the $\mathrm{Ba}_{\mathrm{xs}}$ proxy. In the present work, $\mathrm{O}_{2}$ consumption and POC remineralization were assessed from $\mathrm{Ba}_{\mathrm{xs}}$ inventories and Eqs. (1) and (2). C remineralization rates are given in Table 1. Relative standard uncertainties (Ellison et al., 2000) of $\mathrm{C}$ remineralization ranged between 4 and $20 \%$.

\section{Results}

\subsection{Particulate biogenic $\mathrm{Ba}_{\mathrm{xs}}$ profiles}

$\mathrm{Ba}_{\mathrm{xs}}$ profiles in the upper $800 \mathrm{~m}$ are reported in Fig. 4. The complete whole water column data set is given in Appendix A. From previous studies we know that $\mathrm{Ba}_{\mathrm{xs}}$ in surface waters is distributed over different, mainly non-barite biogenic phases (see Stroobants et al., 1991; Jacquet et al., 2007; Cardinal et al., 2005; Sternberg et al., 2005). As such, these do not reflect POC remineralization processes, in contrast to mesopelagic waters where $\mathrm{Ba}_{\mathrm{xs}}$ is mainly composed of barite (Dehairs et al., 1980) formed during prokaryotic

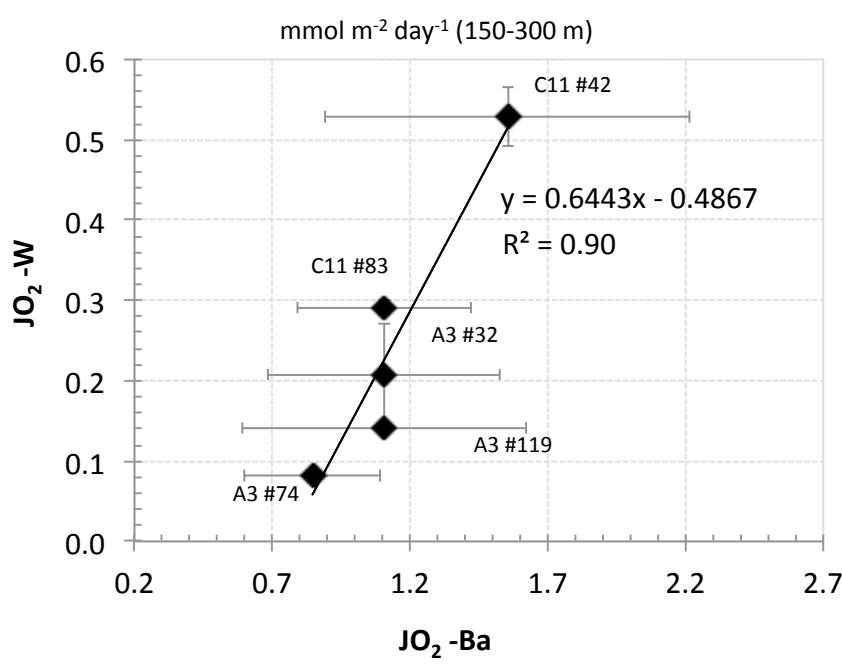

Figure 3. Rates of oxygen consumption $\left(\mathrm{mmol} \mathrm{m}^{-2} \mathrm{day}^{-1}\right)$ during KEOPS 1 as directly measured $\left(\mathrm{JO}_{2}-\mathrm{W}\right)$ and from mesopelagic $\mathrm{Ba}_{\mathrm{xs}}$ contents $\left(\mathrm{JO}_{2}-\mathrm{Ba}\right)$. Rates are integrated between $150-300 \mathrm{~m}$.

degradation of sinking POC (Martin et al., 1987; Sarmiento et al., 1993; Buesseler et al., 2007b). For KEOPS 2 we observed that $\mathrm{Ba}_{\mathrm{xs}}$ concentrations generally increase below $150 \mathrm{~m}$ (i.e. they increase above the background level set at $180 \mathrm{pM}$ ), but some sites have ocean surface $\mathrm{Ba}_{\mathrm{xs}}$ contents significantly larger than background (E-1, $896 \mathrm{pM}$ at $21 \mathrm{~m}$; E4-E, $563 \mathrm{pM}$ at $93 \mathrm{~m}$ ). Such values are not unusual, and very high surface values have been observed occasionally in earlier Southern Ocean studies. During KEOPS 1, surface $\mathrm{Ba}_{\mathrm{xs}}$ maxima at the three A3 repeat stations ranged from 1354 to $5930 \mathrm{pM}$ at $50 \mathrm{~m}$, likely associated with phytoplanktonderived particles (Jacquet et al., 2008a).

The following part focuses on the mesopelagic zone where most of the remineralization of exported organic matter takes place. The $\mathrm{Ba}_{\mathrm{xs}}$ profile for station R-2 (CTD no. 17) displayed a characteristic mesopelagic $\mathrm{Ba}_{\mathrm{xs}}$ maximum, reaching up to $834 \mathrm{pM}$ at $304 \mathrm{~m}$, which is actually one of the highest values observed for the whole study (Fig. $4 \mathrm{a}$ ). $\mathrm{Ba}_{\mathrm{xs}}$ profiles for stations A3 above the Kerguelen Plateau (A3-1 CTD no. 4 and A3-2 CTD no. 107; Fig. 4b) had lower mesopelagic $\mathrm{Ba}_{\mathrm{xs}}$ content, with values ranging from about 80 to $350 \mathrm{pM}$. For both $\mathrm{A} 3$ visits, $\mathrm{Ba}_{\mathrm{xs}}$ values increased close to the seafloor, reaching up to $1108 \mathrm{pM}(\mathrm{A} 3-1,474 \mathrm{~m})$ and $1842 \mathrm{pM}$ (A3-2, $513 \mathrm{~m}$ ). In contrast, station E-4W (located further north along the margin in deeper waters, but with similar $\theta-S$ and Chl $a$ characteristics as station A3) displayed a large mesopelagic $\mathrm{Ba}_{\mathrm{xs}}$ maximum reaching up to $627 \mathrm{pM}$ at $252 \mathrm{~m}$ (Fig. 4c). Station TEW-3 (located on the Kerguelen Plateau, in waters with similar $\theta-S$ and Chl $a$ characteristics as station TNS8) had a profile similar to the one observed at station A3-2, but compared to plateau sites A3-1 and A3-2, no increased $\mathrm{Ba}_{\mathrm{xs}}$ contents were observed in bottom water (Fig. $4 \mathrm{~d}$ ). The other stations of the study area (Fig. $4 \mathrm{~d}-\mathrm{g}$ ) have $\mathrm{Ba}_{\mathrm{xs}}$ pro- 

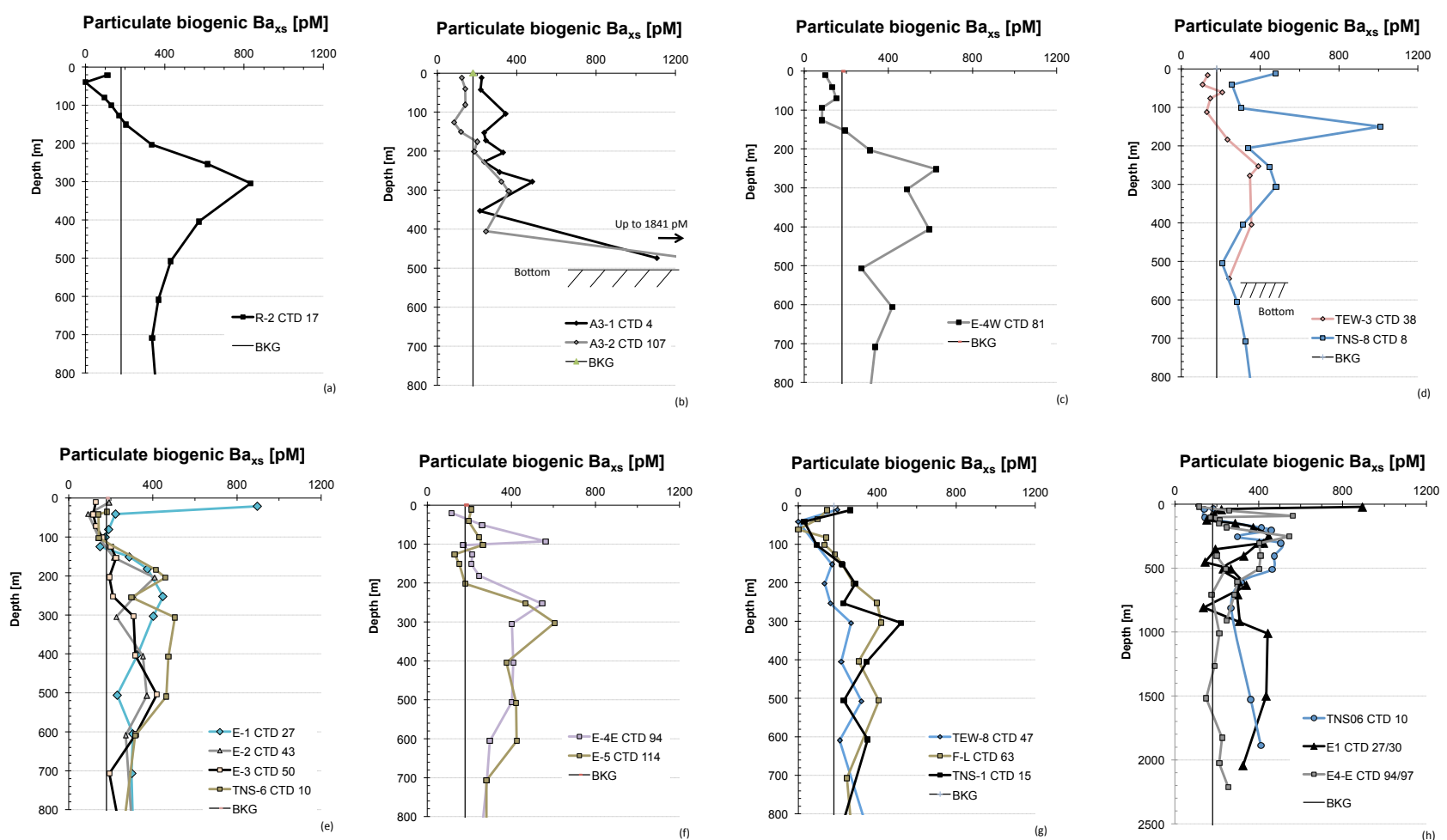

Figure 4. Particulate biogenic $\mathrm{Ba}_{\mathrm{xs}}$ profiles (pM) in the upper $800 \mathrm{~m}$ (Fig. 4a-g) and in the upper $2500 \mathrm{~m}$ (Fig. 4h). Stations are identified by CTD cast numbers. BKG: $\mathrm{Ba}_{\mathrm{xs}}$ background $(180 \mathrm{pM})$.

files similar to the one at station E- $4 \mathrm{~W}$, showing the characteristic $\mathrm{Ba}_{\mathrm{xs}}$ maximum between 200 and $500 \mathrm{~m}$. Note that for most of the stations, $\mathrm{Ba}_{\mathrm{xs}}$ concentrations in waters below the mesopelagic maximum did not systematically decrease to reach the $\mathrm{Ba}_{\mathrm{xs}}$ background level (180 $\mathrm{pM}$; see above). In some cases $\mathrm{Ba}_{\mathrm{xs}}$ contents significantly higher than residual $\mathrm{Ba}_{\mathrm{xs}}$ were observed until below $1000 \mathrm{~m}$ (see Appendix A). This is particularly salient at stations TNS-6, E-1, E-2 and F$\mathrm{L}$ where $\mathrm{Ba}_{\mathrm{xs}}$ values below $1000 \mathrm{~m}$ reach $410 \mathrm{pM}$ at $1886 \mathrm{~m}$ (TNS-6) and $436 \mathrm{pM}$ at $1498 \mathrm{~m}$ (E-1). These cases of high, deep $\mathrm{Ba}_{\mathrm{xs}}$ contents clearly contrasted with the values observed at station E4-E (Fig. 4h).

\subsection{Depth-weighted average $B \mathrm{a}_{\mathrm{xs}}$ content of mesopelagic waters}

Since the base of the mixed layer was generally shallower than $150 \mathrm{~m}$, this depth is taken as the upper boundary of the mesopelagic domain. The depth-weighted average (DWA) $\mathrm{Ba}_{\mathrm{xs}}$ contents, calculated for the $150-400$ and $150-800 \mathrm{~m}$ depth intervals, are given in Table 1. For the profiles on the plateau ( $500 \mathrm{~m}$ water column), bottom waters with evidence of sediment resuspension were not taken into account when calculating DWA $\mathrm{Ba}_{\mathrm{xs}}$ values $(\geq 400 \mathrm{~m})$. Particle size spectra indicated that sediment resuspension occurred especially at stations A3 and TEW-3 (Jouandet et al., 2014; Lasbleiz et al., 2014; van der Merve et al., 2015;). Thus, at site A3
(Fig. 4b), DWA $\mathrm{Ba}_{\mathrm{xs}}$ was calculated for the layer between 150 and $354 \mathrm{~m}$ for A3-1 (CTD no. 4) and between 150 and $405 \mathrm{~m}$ for A3-2 (CTD no. 107). For station TEW-3 (CTD no. 38), DWA $\mathrm{Ba}_{\mathrm{xs}}$ was calculated for the water layer between 150 and $400 \mathrm{~m}$ (Fig. 4d). For the deep sites, we considered both the 150-400 and the 150-800 m depth intervals when calculating the DWA $\mathrm{Ba}_{\mathrm{xs}}$ contents. Depth-weighted average $\mathrm{Ba}_{\mathrm{xs}}$ values were translated into carbon remineralization rates using Eqs. (1) and (2) given above. These rates ranged from 2 to $91 \mathrm{mg} \mathrm{C} \mathrm{m}^{-2} \mathrm{day}^{-1}$ (Table 1).

DWA $\mathrm{Ba}_{\mathrm{xs}}$ values range from 199 to $572 \mathrm{pM}$ (Table 1) and fit within the range reported for polar front areas during previous studies (Cardinal et al., 2001, 2005; Jacquet et al., 2005, 2008a, b, 2011; Planchon et al., 2013). For the KEOPS 2 cruise the main observed features are as follows:

a. Unexpectedly, the highest DWA $B \mathrm{a}_{\mathrm{xs}}$ value of the whole study area $(572 \mathrm{pM} ; 150-400 \mathrm{~m})$ was observed at the reference R-2 site. For R-2, Bowie et al. (2014), Quéroué et al. (2015) and van der Merve et al. (2015) reported local maxima in particulate and dissolved trace metals at $500 \mathrm{~m}$ and deeper, reflecting lateral transport of lithogenic matter possibly originating from the Leclaire Rise (a large seamount located west of R2). Similarly, Lasbleiz et al. (2014) observed a maximum of lithogenic silica (LSi) at $500 \mathrm{~m}$, confirming lithogenic inputs there. However, we note that the 
mesopelagic $\mathrm{Ba}_{\mathrm{xs}}$ maximum at $\mathrm{R}-2$ occurs at shallower depths, around $300 \mathrm{~m}$, and that there is no evidence for elevated values at $500 \mathrm{~m}$ where the previous authors reported higher trace element and silica concentrations. Also, as reported above (see Sect. 2.2 and Appendix A), the higher lithogenic Ba fractions at R-2 (up to $20 \%$ of the total $\mathrm{Ba}$ ) occur only in the upper $80 \mathrm{~m}$. Moreover, we note that surface waters at R-2 has already experienced some nitrate consumption as compared to subsurface winter waters $\left(T_{\min }\right.$ waters). Indeed, surface waters had $10 \%$ less nitrate than winter water $(26 \mu \mathrm{M}$ at $5 \mathrm{~m}$ vs. $29 \mu \mathrm{M}$ at $200 \mathrm{~m}$ ), and the isotopic enrichment of this surface nitrate confirmed a suggestion of uptake (see Dehairs et al., 2014). Also, Lasbleiz et al. (2014) reported relatively low $\mathrm{Si}: \mathrm{C}$ and $\mathrm{Si}: \mathrm{N}$ ratios for surface ocean suspended matter), pointing to the development of a diatom assemblage just prior to the sampling, consistent with the high dissolution rates of biogenic silica (BSi) that Closset et al. (2014) reported for R-2 surface waters. It is therefore likely that the mesopelagic $\mathrm{Ba}_{\mathrm{xs}}$ content at $\mathrm{R}-2$ indeed reflects remineralization of organic material that was fuelled by an important past early spring production and export event. Similarly, during late winter (November 1993) F. Dehairs (unpublished results) observed the presence of significant numbers of barite microcrystals in mesopelagic waters at the KERFIX time series station $\left(50^{\circ} 40^{\prime} \mathrm{S}, 68^{\circ} 25^{\prime} \mathrm{E}\right)$ located east of R-2. Results would thus suggest the occurrence in this HNLC area of recurrent brief early spring diatom productive period pulses and subsequent export and remineralization activity in the underling layers. Chl $a$ satellite images (Giovanni - Interactive Visualization and Analysis, NASA GES DISC) corroborate that the R-2 and KERFIX area is occasionally subject to enhanced biomass during early spring;

b. The two successive visits ( 27 days apart) at site A3 yielded relatively low DWA $\mathrm{Ba}_{\mathrm{xs}}$ values of 267 and $316 \mathrm{pM}$, and a quite similar value was observed for the shallow station TEW-3 (324 pM), located further north on the plateau and north of the PF. Note that for comparison purposes, we recalculated the DWA $\mathrm{Ba}_{\mathrm{xs}}$ and MR values of KEOPS 1 by considering upper and lower mesopelagic layer boundaries of 150 and $400 \mathrm{~m}$ rather than 125 and $450 \mathrm{~m}$, as in Jacquet et al. (2008a). Also, in the aforementioned study the high $\mathrm{Ba}_{\mathrm{xs}}$ contents observed near the seafloor were not excluded from the calculations, while they are here. These increased benthic boundary layer $\mathrm{Ba}_{\mathrm{xs}}$ contents (observed also during KEOPS 2) are due to sediment resuspension which extended up to $70 \mathrm{~m}$ above the seafloor during KEOPS 1 (Blain et al., 2008; Venchiarutti et al., 2008; Armand et al., 2008). Because of these slightly different depth intervals over which $\mathrm{Ba}_{\mathrm{xs}}$ values were integrated, the KEOPS 1 values discussed here will be slightly differ- ent from those reported in Jacquet et al. (2008a). At the other depths, the lithogenic Ba contribution at A3 (KEOPS 2) was only minor;

c. The time series stations in the polar front meander had DWA $\mathrm{Ba}_{\mathrm{xs}}$ contents ranging from 258 to $427 \mathrm{pM}$ $(150-400 \mathrm{~m})$, so reaching values exceeding those on the plateau. For these time series, stations' values decreased between day 0 (TNS-6) and 12 (E-3), and then increased again at days 22 (E-4E) and 27 (E-5). Stations E-4W and TNS-8, above the plateau but in deeper waters close to the Kerguelen margin, at the edge the high biomass plume (Fig. 1), had the highest DWA $\mathrm{Ba}_{\mathrm{xs}}$ values (468 and $473 \mathrm{pM}$, respectively; $150-400 \mathrm{~m}$ ), not considering the R-2 reference station. The polar front F-L site, although located within the eastern part of the high biomass plume, had a smaller DWA $\mathrm{Ba}_{\mathrm{xs}}$ value of $345 \mathrm{pM}(150-400 \mathrm{~m})$ and the nearby station TEW-8 had the lowest DWA $\mathrm{Ba}_{\mathrm{xs}}$ value of the whole study area (199 pM; 150-400 m).

\section{Discussion}

\subsection{Mesopelagic $B \mathrm{a}_{\mathrm{xs}}$ and bacterial production}

Previous studies revealed that the shape of the columnintegrated bacterial production (BP) profile (i.e. the attenuation length scale) was important in setting the $\mathrm{Ba}_{\mathrm{xs}}$ signal in the mesopelagic zone (Dehairs et al., 2008; Jacquet et al., 2008a, 2011a). Mesopelagic $\mathrm{Ba}_{\mathrm{xs}}$ content is smaller when most of the column-integrated BP is restricted to the upper mixed layer (indicating an efficient, near-complete remineralization within the surface), compared to situations where a significant part of integrated BP was located deeper in the water column (reflecting significant deep bacterial activity and POC export). During KEOPS 2 the incorporation of ${ }^{3} \mathrm{H}-$ leucine was used to estimate bacterial production. BP data are described in Christaki et al. (2014). In Fig. 5 we compare column-integrated BP at $150 \mathrm{~m}$ over $400 \mathrm{~m}$ (BP150/400) and DWA $\mathrm{Ba}_{\mathrm{xs}}$ for the $150-400 \mathrm{~m}$ depth interval, along with the relationship obtained during KEOPS 1 (BP200/125 and 150-450 m DWA Ba ${ }_{x s}$; Jacquet et al., 2008a; Christaki et al., 2008). Excluding stations A3, E-1, E-2 and E-3, KEOPS 2 data presented a significant correlation $\left(R^{2}=0.88 ; p<0.01\right)$ and a similar trend to the one reported for KEOPS 1 . A similar picture was obtained when integrating DWA $\mathrm{Ba}_{\mathrm{xs}}$ and $\mathrm{BP}$ up to $800 \mathrm{~m}$ (not shown). The time series " $\mathrm{E}$ " stations in the meander revealed a shift from stations E-1, E-2 and E-3 to stations E-4E and E-5, i.e. towards the trend reported above. A shift was also apparent at station A3 from KEOPS 2 (early spring) to KEOPS 1 (late summer). It is thus possible that results reflect the occurrence of different stages of bloom advancement. The large variability of the $\mathrm{Ba}_{\mathrm{xs}}$ and $\mathrm{BP}$ relationship during KEOPS 2, especially at A3 site and in the me- 
Table 2. Comparison of mesopelagic POC remineralization (MR) with primary production (PP) and export production (EP). All fluxes in $\mathrm{mg} \mathrm{C} \mathrm{m}^{-2} \mathrm{day}^{-1} . r$ ratio is the ratio of Mr over EP. The $\mathrm{C}$ sequestration (or transfer) efficiency at 400 and $800 \mathrm{~m}$ (T400, T800) is the fraction of $\mathrm{C}$ export (EP) at $150 \mathrm{~m}$ exiting through the $400 \mathrm{~m}$ (T400) or the $800 \mathrm{~m}$ (T800) horizons. See text for further information on calculation.

\begin{tabular}{|c|c|c|c|c|c|c|c|c|c|c|c|c|}
\hline Station & CTD & $\begin{array}{c}\text { MLD } \\
{[\mathrm{m}]}\end{array}$ & $\begin{array}{l}\mathrm{Ez}^{\mathrm{b}} \\
{[\mathrm{m}]}\end{array}$ & $\begin{array}{c}\mathrm{PP}^{\mathrm{c}} \mathrm{Ez} \\
{\left[\mathrm{mgCm}^{-2} \mathrm{day}^{-1}\right]}\end{array}$ & $\begin{array}{c}\mathrm{EP}^{\mathrm{d}} \\
150 \mathrm{~m} \\
{\left[\mathrm{mg} \mathrm{Cm}^{-2} \mathrm{day}^{-1}\right]}\end{array}$ & $\begin{array}{c}\text { MR } \\
150-400 \mathrm{~m} \\
{\left[\mathrm{mg} \mathrm{Cm}^{-2} \text { day }^{-1}\right]}\end{array}$ & $\begin{array}{c}\mathrm{MR} \\
150-800 \mathrm{~m} \\
{\left[\mathrm{mg} \mathrm{Cm}^{-2} \text { day }^{-1}\right]}\end{array}$ & $\mathrm{EP} / \mathrm{PP}$ & $\begin{array}{c}r \text { ratio } \\
150-400 \mathrm{~m}\end{array}$ & $\begin{array}{c}r \text { ratio } \\
150-800 \mathrm{~m}\end{array}$ & T400 & T800 \\
\hline \multicolumn{13}{|l|}{ Plateau } \\
\hline A3-1 & $4^{\mathrm{a}}$ & 161 & - & - & 47 & 14 & - & - & 0.29 & - & 0.70 & - \\
\hline A3-2 & $107^{\mathrm{a}}$ & 165 & 38 & 2172 & 85 & 11 & - & 0.04 & 0.13 & - & 0.87 & - \\
\hline \multicolumn{13}{|c|}{ Reference site } \\
\hline $\mathrm{R}-2$ & $17 / 20$ & 111 & 92 & 132 & 30 & 50 & 91 & 0.23 & 1.65 & 3.02 & 0 & 0 \\
\hline \multicolumn{13}{|c|}{ Meander time series } \\
\hline E-1 & $27 / 30$ & 84 & 64 & 578 & 100 & 26 & 48 & 0.17 & 0.26 & 0.48 & 0.74 & 0.52 \\
\hline E-3 & $50 / 55$ & 41 & 68 & 748 & 130 & 10 & 35 & 0.17 & 0.08 & 0.27 & 0.92 & 0.73 \\
\hline E-4E & $94 / 97$ & 77 & 34 & 1037 & 48 & 27 & 58 & 0.05 & 0.57 & 1.21 & 0.43 & 0 \\
\hline E-5 & $113 / 114$ & 36 & 54 & 1064 & 84 & 28 & 66 & 0.08 & 0.33 & 0.78 & 0.67 & 0.22 \\
\hline \multicolumn{13}{|c|}{ Polar front zone } \\
\hline F-L & $63 / 68$ & 21 & 29 & 3380 & 43 & 21 & 49 & 0.01 & 0.48 & 1.13 & 0.52 & 0 \\
\hline \multicolumn{13}{|c|}{ Polar front } \\
\hline E-4W & $81 / 87$ & 67 & 31 & 3287 & 54 & 36 & 76 & 0.02 & 0.67 & 1.41 & 0.33 & 0 \\
\hline
\end{tabular}

${ }^{a}$ Station A3 (CTD4 and 107); MR integrated up to 354 and $405 \mathrm{~m} .{ }^{\mathrm{b}}$ Ez euphotic layer (until 1\% PAR level). ${ }^{\mathrm{c}}$ PP data from Cavagna et al. (2015). ${ }^{\mathrm{d}}$ EP data from Planchon et al. (2015).

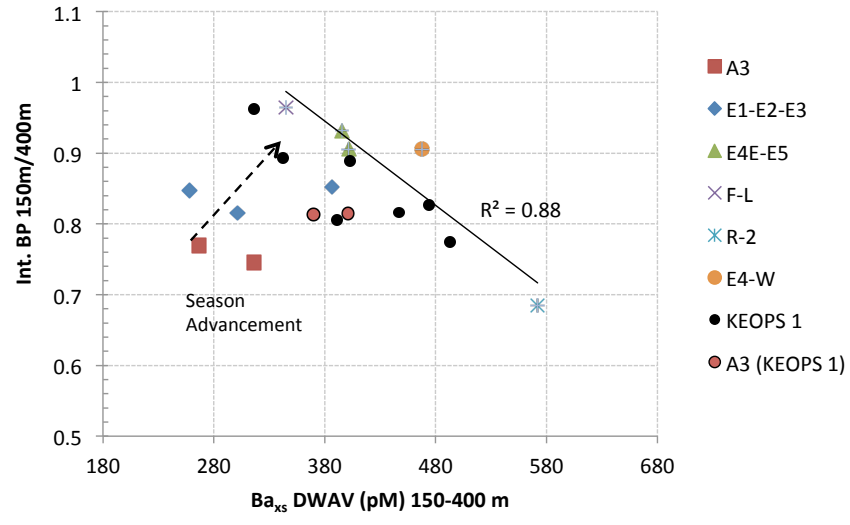

Figure 5. Regression of the ratio of integrated bacterial production (BP) in the upper $150 \mathrm{~m}$ over integrated BP in the upper $400 \mathrm{~m}$ versus depth-weighted average (DWA) mesopelagic $\mathrm{Ba}_{\mathrm{xs}}$ (pM; 150$400 \mathrm{~m}$ ) during KEOPS 2. KEOPS 1 data (dots) are reported for comparison (Christaki et al., 2008; Jacquet et al., 2008a).

ander, could reflect the temporal evolution and patchiness of the establishment of mesopelagic remineralization processes in this polar front area.

\subsection{Fate of exported organic $\mathrm{C}$ in the mesopelagic zone and deep water column}

An important question relates to the fate of the exported POC: how much of this POC is respired in the mesopelagic waters and how much escapes remineralization and is exported to deeper layers where longer-term sequestration is likely (see e.g. Passow and Carlson, 2012; Robinson et al., 2014; Schneider et al., 2008). To address these questions, we defined two ratios: (1) the mesopelagic $\mathrm{C}$ remineralization efficiency ( $r$ ratio in Table 2), which is the ratio of mesopelagic $\mathrm{C}$ remineralization (MR, based on the DWA $\mathrm{Ba}_{\mathrm{xs}}$ concentrations) over $\mathrm{C}$ export (EP) from the $150 \mathrm{~m}$ horizon (based on ${ }^{234} \mathrm{Th}$, see Planchon et al., 2014), and (2) the $\mathrm{C}$ transfer efficiency at 400 and $800 \mathrm{~m}$ (i.e. T400, T800 in Table 2), which is the fraction of $\mathrm{C}$ export (EP) at $150 \mathrm{~m}$ passing through the $400 \mathrm{~m}$ (T400) or the $800 \mathrm{~m}(\mathrm{~T} 800)$ horizons (e.g. T400 $=\mathrm{EP} 400 / \mathrm{EP} 150=1-$ $(\mathrm{MR} / \mathrm{EP} 150)$, with $\mathrm{MR} / \mathrm{EP} 150=r$ ratio; see above). This approach is similar to the one developed by Buesseler and Boyd (2009) stating that a conventional curve-fitting of particle flux data (i.e. power law or exponential) skews our interpretation of the mesopelagic processes. They recommended the use of combined metrics to capture and compare differences in flux attenuation. In the following, we compare MR fluxes for the different KEOPS 2 areas (reference site; plateau sites; polar front and polar front meander) and discuss remineralization and transfer efficiencies for those sites for which MR, primary production (PP) and/or EP data (Table 2) were available. PP data were estimated from uptake experiments including $24 \mathrm{~h}$ incubations at different PAR levels over the euphotic layer, i.e. up to the $0.01 \%$ PAR level (Cavagna et al., 2014). EP data were estimated from ${ }^{234} \mathrm{Th}$ activities and ${ }^{234} \mathrm{Th} / \mathrm{POC}$ ratios and are discussed in Planchon et al. (2014). The thorium method integrates POC export over a 1-month period $\left({ }^{234} \mathrm{Th}\right.$ half live is 24.1 days). We remind the reader here that MR fluxes based on mesopelagic $\mathrm{Ba}_{\mathrm{xs}}$ reflect past remineralization activity integrated over several days to a few weeks (Dehairs et al., 1997; Cardinal et al., 2005; Jacquet et al., 2007, 2008b). In order to compare 
EP with MR ( $r$ ratio and transfer efficiency), we consider EP fluxes from $150 \mathrm{~m}$. Results are compared with late summer KEOPS 1 results. For KEOPS 1, PP data are detailed in Lefèvre et al. (2008) and Mosseri et al. (2008), EP data are detailed in Savoye et al. (2008) and $\mathrm{Ba}_{\mathrm{xs}}$ data are described in Jacquet et al. (2008a).

\subsubsection{Reference station R-2}

Since station R-2 had the highest DWA $\mathrm{Ba}_{\mathrm{xs}}$ content, it yielded the highest MR flux of the whole study area (91 $\mathrm{mg}$ $\mathrm{C} \mathrm{m}^{-2}$ day $^{-1} ; 150-800 \mathrm{~m}$; Table 2). In contrast, both PP and EP fluxes at R-2 were very low (132 and $10 \mathrm{mg} \mathrm{C} \mathrm{m}^{-2}$ day $^{-1}$, respectively) and the calculated MR flux exceeded EP (Table 2). The resulting export efficiency (EP/PP) was high, and T400 and T800 values (the fraction of EP exported deeper than 400 and $800 \mathrm{~m}$, as defined above) equal 0 (i.e. no export of POC beyond 400 and $800 \mathrm{~m}$; note that $>100 \%$ values, i.e. MR $>$ EP, were set to zero in Fig. 7a and Table 2). The fact that MR exceeds EP therefore implies a non-steady state condition at the R-2 site. As reported above, R-2 probably experienced a brief early spring diatom production pulse days to a few weeks before the start of the KEOPS 2 cruise, followed by subsequent export and very important remineralization activity in the underling layers as depicted by MR data.

\subsubsection{Station A3 on the plateau}

The MR fluxes on the plateau varied little between the two visits 27 days apart (Table 1) and, moreover, as discussed below they were similar to summer values obtained during KEOPS 1 (see Jacquet et al., 2008a) when the same A3 site was sampled three times over a 19-day period. While during KEOPS 2 (spring) MR fluxes at A3 ranged from 11 to $14 \mathrm{mg} \mathrm{C} \mathrm{m}^{-2}$ day $^{-1}$ (with a standard uncertainty of around $5 \%$ ), they were slightly larger during KEOPS 1 (summer; 17 to $23 \mathrm{mg} \mathrm{C} \mathrm{m}^{-2}$ day $^{-1}$ ) (Fig. 5). We observed differences in the mesopelagic POC remineralization efficiency between the two seasons ( $r$ ratio, blue values in Fig. 6, Table 2). During KEOPS $1, r$ ratios (MR / EP) remained low, ranging from 7 to $9 \%$ of EP at A3, while during KEOPS 2, $r$ ratios were slightly higher but decreased from $29 \%$ (A3-1; first visit) to $13 \%, 27$ days later (A3-2; second visit). This variation in $r$ ratio during KEOPS 2 is mostly due to an increase of EP (from 47 to $85 \mathrm{mg} \mathrm{C} \mathrm{m}^{-2}$ day $^{-1}$; Planchon et al., 2014) over the same period while MR showed little change. Although at this early stage of the season (spring) PP at A32 had already reached $2172 \mathrm{mg} \mathrm{C} \mathrm{m}^{-2}$ day $^{-1}$ (Cavagna et al., 2014), EP remained relatively low $\left(85 \mathrm{mg} \mathrm{C} \mathrm{m}^{-2}\right.$ day $\left.^{-1}\right)$. Here EP accounted for only about $4 \%$ of PP (low export efficiency; see green data points in Fig. 5). These conditions suggested that phytoplankton biomass had accumulated in the surface waters without significant export at that point, or that $\mathrm{C}$ had been channelled to higher trophic levels as suggested by Christaki et al. (2014). Note that a negative relationship between primary productivity and surface carbon export efficiency has already been reported from previous studies in the Southern Ocean (Lam et al., 2007; Morris et al., 2007; Savoye et al., 2008; Jacquet et al., 2011a, b). Among possible explanations for the occurrence of highproductivity low export efficiency regimes in high-latitude systems Maiti et al. (2013) mentioned differences in trophic structure, grazing intensity, recycling efficiency, high bacterial activity or increase in DOC export, but the exact reason remain unclear. In contrast, during KEOPS 1 (summer), EP fluxes reached $250 \mathrm{mg} \mathrm{C} \mathrm{m}^{-2} \mathrm{day}^{-1}$ at $125 \mathrm{~m} \mathrm{(14-31 \%}$ of PP), while PP ranged from 865 to $1872 \mathrm{mg} \mathrm{C} \mathrm{m}^{-2} \mathrm{day}^{-1}$, reflecting enhanced export efficiency (Jacquet et al., 2008a; Savoye et al., 2008).

It is important to underline the fact that MR at station A3 was only slightly higher in summer than in spring, especially considering the large differences in export efficiency between seasons. According to results from sediment traps deployed over 1 year at the A3 site, Rembauville et al. (2014) reported that $60 \%$ of the annual POC export at the base of the mixed layer occurred over a short periods of time representing $<4 \%$ of the year and was composed of small highly silicified, fast-sinking, resting spores of diatoms that bypass grazing pressure. According to these authors, the pulses are linked to nutrient depletion dynamics inducing resting spore formation. During the rest of the year, the flux was composed of small diatoms (empty frustules) and small fecal pellets, with efficient $\mathrm{C}$ retention in the surface layer or transfer to trophic levels. If we consider that export conditions during KEOPS 2 are more similar to those prevailing most of the year, it is surprising that during KEOPS 1 (which would reflect an export event toward the end of the growth season) MR is not more important. This would indicate that fast-sinking, highly silicified and pulsed material was directly transferred to the bottom without major remineralization. Note for example that at the complex R-2 reference station, a small export event (Laurenceau-Cornec et al.; 2015) held heavily silicified diatoms (Lasbleiz et al., 2014) and that the material was efficiently remineralized in the upper mesopelagic layer as witnessed by the high MR values we observed for that station. For the KEOPS 2 A3 site, Laurenceau-Cornec et al. (2015) reported that the sinking flux collected in the upper layer using gel-filled sediment traps was composed of phytodetrital aggregates that held slightly silicified diatoms (Lasbleiz et al., 2014). Even considering the shift from slightly to highly silicified material transfer between spring (KEOPS2) and summer (KEOPS 1), MR only slightly increases between both periods. Also, the mesozooplankton biomass at A3-2 was one of the highest of the KEOPS2 cruise, with a doubling from KEOPS 2 (early spring) to KEOPS 1 (late summer) (Carlotti et al., 2015). It is thus possible that at $\mathrm{A} 3$ the export event reported above, combined with a lasting grazing pressure, could have induced this rather low and enduring mesopelagic remineralization. 
KEOPS 2

(Early spring 2011)
KEOPS 1

(Late summer 2005)

\begin{tabular}{|c|c|c|c|c|c|}
\hline \multirow{3}{*}{ PP } & & \multicolumn{2}{|r|}{ A3-2 } & \multicolumn{2}{|c|}{ Mean of the 3 repeats } \\
\hline & Not available & \multicolumn{2}{|r|}{2172} & \multicolumn{2}{|c|}{$864-1872$} \\
\hline & & & $\downarrow \quad 4 \%$ & & $\downarrow \quad 14-31 \%$ \\
\hline EP & 47 & & 85 & & 250 \\
\hline & $\downarrow^{29 \%}$ & $<1 \%$ & $\downarrow^{13 \%}$ & $1-2 \%$ & $7-9 \%$ \\
\hline MR & 14 & & 11 & & $17-23$ \\
\hline
\end{tabular}

All fluxes in $\mathrm{mgC} \mathrm{m}^{-2}$ day $^{-1}$

Blue values: $r$ ratio, mesopelagic remineralization efficiency (MR/EP)

Green values: EP/PP

Red values: MR/PP

Figure 6. Schematic, comparing the fate of POC at station A3 during KEOPS 1 and KEOPS 2 cruises. PP: primary production, EP: export production at $150 \mathrm{~m}$ depth and MR: mesopelagic POC remineralization deduced from the $\mathrm{Ba}_{\mathrm{xs}}$ maxima and integrated between $150-400 \mathrm{~m}$; all fluxes in $\mathrm{mgC} \mathrm{m}^{-2} \mathrm{day}^{-1}$. EP/PP (green values), MR/PP (red values) and MR/EP ( $r$ ratio, blue values) ratios shown as percentage.
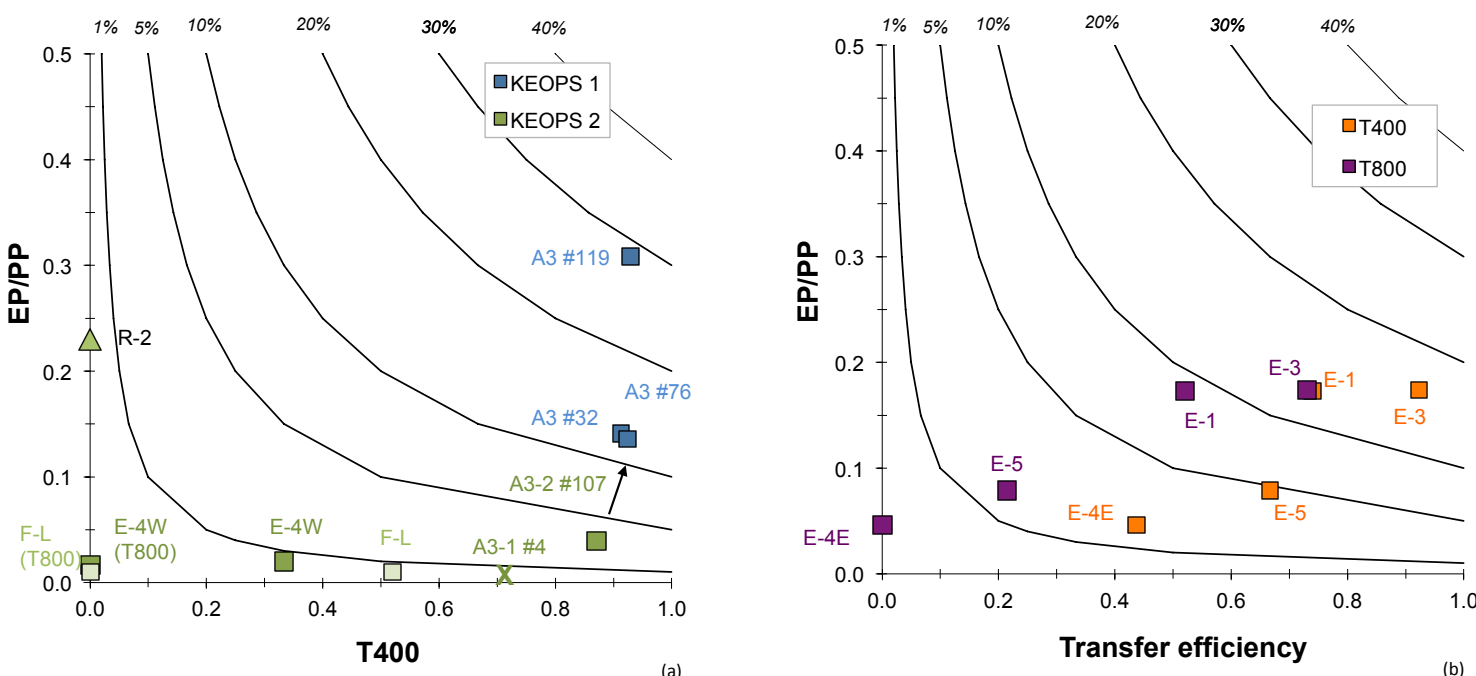

Figure 7. $y$ axis: $\mathrm{EP} / \mathrm{PP}=\mathrm{POC}$ flux at $150 \mathrm{~m}(\mathrm{EP} 150)$ as a fraction of primary production $(\mathrm{PP}) ; x$ axis: $\mathrm{EPx} / \mathrm{EP} 150=\mathrm{POC}$ flux at defined depths (EPx; here 400 and $800 \mathrm{~m}$ ) as a fraction of POC flux at $150 \mathrm{~m}$ (EP150). The green cross (Fig. 5a) is for station A3-1 (KEOPS-2). Since no PP data are available for that station, the EP/PP value has been set to 0 . Isolines represent the modelled 1, 5, 10, 20 and $30 \%$ of PP export to depths $>$ at 400 or $800 \mathrm{~m}$, and represent export efficiency.

We also wonder if the shallow water column at A3 combined with lateral advection above the plateau plays a role in triggering the mesopelagic POC remineralization activity and in setting its efficiency. For KEOPS 1, Venchiarutti et al. (2008) reported that lateral advection over the plateau could significantly impact particle dynamics. During KEOPS 1, station B1 (CTD68), located on the plateau upstream from A3 according to the plateau circulation (Park et al., 2008), exhibited a very similar $\mathrm{Ba}_{\mathrm{xs}}$ distribution as station $\mathrm{A} 3$ : low mesopelagic $\mathrm{Ba}_{\mathrm{xs}}$ and important bottom resuspension (not shown here; see Jacquet et al., 2008a). These strong similarities in $\mathrm{Ba}_{\mathrm{xs}}$ profile shapes would indicate that next to the pulsed nature of the events, the dynamics on the shallow plateau play an important role in limiting the extent of mesopelagic POC remineralization processes.
In Fig. 7a, the ratio of EP to PP (export efficiency) vs. the fraction of EP exported deeper than $400 \mathrm{~m}$ (i.e. T400; defined above) is shown for both KEOPS cruises. Note that for station A3-1 (KEOPS 2), there are no PP data. The A3 site shows increasing EP/PP ratios from spring (KEOPS 2) to late summer (KEOPS 1), and so do the T400 values (A3-1: 70\%; A3-2: $87 \%$; KEOPS 1 A3 site: $92 \pm 1 \%$ ). Station E$4 \mathrm{~W}$ is located in waters with similar $\theta-S$ and Chl $a$ characteristics as the $\mathrm{A} 3$ plateau site but has a deeper water column (1384 $\mathrm{m}$ has PP and EP fluxes of the same order of magnitude (Table 2)). However, MR values (36 mg C m${ }^{-2} \mathrm{day}^{-1} ; 150$ $400 \mathrm{~m}$ ) are larger at E-4W, resulting in a lower T400 value of around $33 \%$, compared to $87 \%$ for A3-2 (Fig. 7a). When integrating between 150 and $800 \mathrm{~m}, \mathrm{~T} 800$ at E-4W equals 0 (i.e. no export of POC beyond $800 \mathrm{~m}$; Fig. 7a and Table 2). 


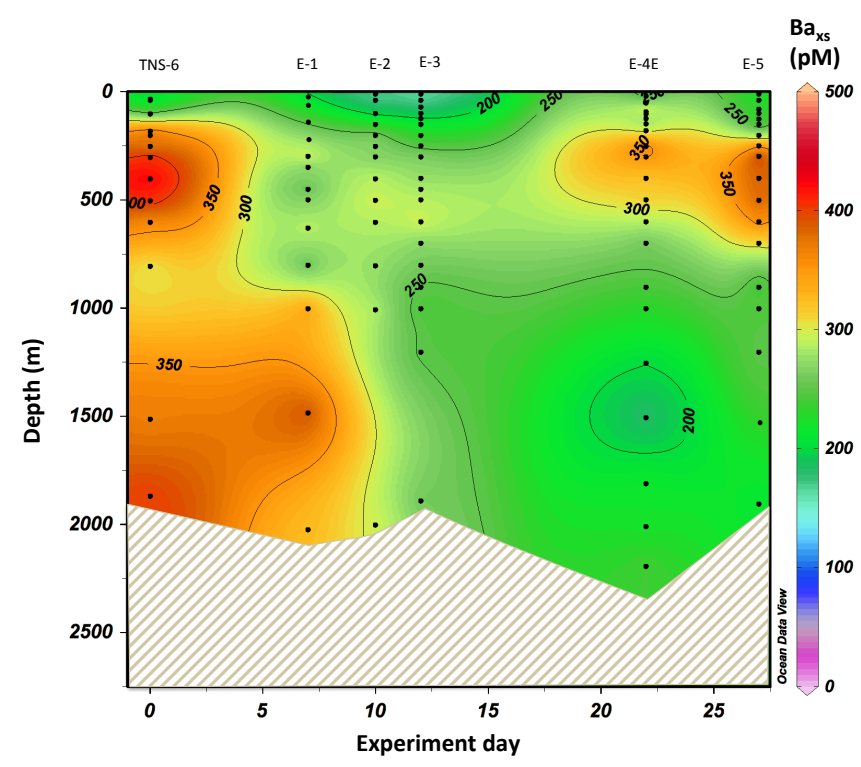

Figure 8. Temporal evolution of particulate biogenic $\mathrm{Ba}\left(\mathrm{Ba}_{\mathrm{xs}} ; \mathrm{pM}\right)$ in the upper $2000 \mathrm{~m}$ water column in the polar front meander. Graph constructed using Ocean Data View (Schlitzer, 2002; Ocean Data View; http://www.awi-bremerhaven.de/GEO/ODV).

Station F-L (in the vicinity of the PF; $74.7^{\circ} \mathrm{E}$ ) appears to function in a similar way as observed for $\mathrm{E}-4 \mathrm{~W}\left(71.4^{\circ} \mathrm{E}\right)$. $\mathrm{PP}$ at station F-L is relatively high (3380 $\mathrm{mg} \mathrm{C} \mathrm{m}^{-2}$ day $^{-1}$ ), while EP is quite low $\left(43 \mathrm{mg} \mathrm{C} \mathrm{m}{ }^{-2}\right.$ day $\left.^{-1}\right)$, reflecting the fact that the biomass was not yet exported from the surface waters or was transported to higher trophic levels. Since MR fluxes are slightly lower $\left(21 \mathrm{mg} \mathrm{C} \mathrm{m}{ }^{-2}\right.$ day $\left.^{-1} ; 150-400 \mathrm{~m}\right)$ at F-L than at E-4W, resulting T400 values are higher (52\%) there.

Overall, during KEOPS 2, it appears that biomass at stations A3, E-4W and F-L (sites of high productivity) had been accumulating in surface waters (e.g. transfer to higher trophic levels) and export had not yet started, considering the early stage of the season during KEOPS 2. Our observations allow us to conclude the following:

1. Both seasons (KEOPS 1 and KEOPS 2) showed a similar functioning of the mesopelagic ecosystem at A3. The rather low and enduring MR fluxes under high production and variable export regimes (high export efficiency during KEOPS 1 and low export efficiency during KEOPS 2) indicated that here mesopelagic remineralization does not represent a major resistance to organic matter transfer to the seafloor at A3. On average (considering both seasons, but excluding A3-1), the C transfer efficiency into the deep $(>400 \mathrm{~m})$ as assessed by PP, EP and MR fluxes comparisons reached $91 \pm 3 \%$ at A3;

2. In contrast to A3, E-4W and F-L showed important mesopelagic remineralization rates, reducing the effi- ciency of $\mathrm{C}$ transfer beyond $400 \mathrm{~m}$ to 33 and $52 \%$, respectively, and to zero for both stations beyond $800 \mathrm{~m}$. Bottom depth, lateral advection, zooplankton grazing pressure and the pulsed nature of the POC transfer at A3 were the particular conditions that could drive the differences in $\mathrm{C}$ transfer efficiency between $\mathrm{A} 3$ and E4$\mathrm{W}$ and F-L and limit the extent of MR processes at A3.

\subsection{Stations in the meander}

Temporal short-term changes for the stations TNS-6, E-1, E2, E-3, E-4E and E-5, located in the polar front meander, will be discussed in this section. Note that no PP or EP data exist for TNS-6. From Table 2 it appears that PP almost doubled between E-1 and E-5, but this increase was not paralleled by an increase of EP and MR, except for the $30 \% \mathrm{EP}$ increase from E-1 to E-3. In fact, overall EP shows a decreasing trend with time, while MR (150-400 m) stays rather constant, except for the decrease between E-1 and E-3 (Table 2). As reported above such a mismatch may result from differences in timescales characterizing the different processes that were compared. The most likely explanation is that in this early stage of the growth season, phytoplankton biomass accumulated in the surface layer and export lagged behind.

The ratio of EP to PP vs. T400 and T800 showed a large variability in transfer efficiency inside the meander (Fig. 7b). PP and EP fluxes increased by about $30 \%$ from E-1 to E-3, but a concomitant decrease of mesopelagic MR yielded to an enhanced transfer efficiency, from 74 to $92 \%$, through the $400 \mathrm{~m}$ boundary, and from 52 to $73 \%$ through the $800 \mathrm{~m}$ boundary. This suggests that significant remineralization should have occurred at greater depths (even $>1000 \mathrm{~m}$ ), and it is also reflected by the presence of $\mathrm{Ba}_{\mathrm{xs}}$ maxima below $1000 \mathrm{~m}$ (see Fig. 4h and Appendix A). This was particularly salient when plotting $\mathrm{Ba}_{\mathrm{xs}}$ contents vs. depths over the 27day observation period (Fig. 8). The high, deep water $\mathrm{Ba}_{\mathrm{xs}}$ values in Fig. 8 were not taken into account when integrating TNS- 6 and E- 1 profiles between 150 and 400 or even 150 and $800 \mathrm{~m}$ (Fig. 5e). Considering that the seafloor in the meander area is at about $2000 \mathrm{~m}$ depth, it seems unlikely that these high $\mathrm{Ba}_{\mathrm{xs}}$ contents at depths $>1000 \mathrm{~m}$ were due to sediment resuspension. Also, particle spectra for these sites do not reveal any bottom resuspension (Jouandet et al., 2014; Lasbleiz et al., 2014; van der Merve et al., 2015). Therefore, the high, deep (>1000 m) Ba $\mathrm{x}_{\mathrm{xs}}$ contents at TNS-6 and E-1 most likely reflects the fact that here significant remineralization of POC material actually did occur in the bathypelagic domain and even down to the seafloor. Note that suspended particles in the depth range containing the deep $\mathrm{Ba}_{\mathrm{xs}}$ maxima were dominated by the $<2 \mu \mathrm{m}$ size fraction (M. Zhou, personal communication, 2014). When integrating the $\mathrm{Ba}_{\mathrm{xs}}$ contents from $150 \mathrm{~m}$ to the seafloor at stations TNS- 6 and E-1, MR fluxes increase to 156 and $184 \mathrm{mg} \mathrm{C} \mathrm{m}^{-2}$ day $^{-1}$, respectively. Such $\mathrm{C}$ fluxes were similar to the EP values (maximum value of $130 \mathrm{mg} \mathrm{C} \mathrm{m}^{-2}$ day $^{-1}$ at E-3) and suggested that the exported 
POC was entirely remineralized in the water column leaving no $\mathrm{C}$ for transfer to the sediments.

Overall, the temporal pattern of mesopelagic remineralization described above reflects two successive events of particle transfer: a first transfer from a previous bloom (occurred before visiting TNS- 6 and enduring at E-1) and a second transfer from E-4E to E-5. The first transfer was evidenced by the downward (to the bottom) propagation of the mesopelagic $\mathrm{Ba}_{\mathrm{xs}}$ maximum signal, which mostly weakens at $\mathrm{E}-2$. The second event was reflected by the occurrence again of important mesopelagic $\mathrm{Ba}_{\mathrm{xs}}$ build-up at E-4E and E-5. Overall, our results indicated the large capacity of the polar front meander to transfer POC material to depth, but in contrast to station A3 on the plateau, this transfer was coupled to intense and near-complete POC remineralization (as also observed at E$4 \mathrm{~W}$ and F-L). Between-site changes in mesopelagic carbon remineralization due to unequal biomass productivity and iron fertilization over the Kerguelen Plateau were thus relatively complex. Furthermore, the conditions in the meander area seems to corroborate results obtained in the iron-replete Subantarctic Zone east of the Tasman Plateau (Australian sector of the Southern Ocean; SAZ-Sense cruise; Jacquet et al., 2011a, b), where the mesopelagic remineralization efficiency reported was relatively high (on average $91 \%$ ) and the deep $(>600 \mathrm{~m})$ carbon transfer weak $(<10 \%)$. Finally, the important $\mathrm{Ba}_{\mathrm{xs}}$ contents reported between 1000 and $2000 \mathrm{~m}$ during the first stages of the meander time-series support recent results indicating for the Southern Ocean that $1000 \mathrm{~m}$ is insufficient as an ocean-wide reference for carbon transfer and sequestration potential (Robinson et al., 2014).

\section{Conclusions}

Based on spatially and temporally well-resolved mesopelagic excess particulate $\mathrm{Ba}$ inventories, this work estimated mesopelagic POC remineralization above the Kerguelen Plateau and inside a permanent meander of the polar front to the east of plateau. The observed variability of mesopelagic remineralization reflects differences in the fate of the biomass that is exported to the deep ocean between the plateau and polar front. Results also reveal the patchiness of the seasonal advancement and of the establishment of remineralization processes between these sites. Our results indicate that a few days to weeks before the start of the cruise, the reference station R-2 experienced an export event that was efficiently remineralized in the upper mesopelagic layer. In terms of deep ocean carbon transfer efficiency, our results highlight that above the plateau (A3 site), mesopelagic remineralization is not a major barrier to organic matter transfer to the seafloor, with carbon transfer beyond $400 \mathrm{~m}$ reaching up to $87 \%$ of EP during KEOPS 2, while in the polar front meander, remineralization of exported organic carbon in the upper $400 \mathrm{~m}$ is more efficient than above the plateau. In the meander area, remineralization may even balance export when including its effect in the deeper waters (up to $800 \mathrm{~m}$ and even deeper), thus resulting in a near-zero carbon transfer to sediment. A similar condition is also observed for sites at the margin of the plateau (E-4W) and the polar front (F-L). 


\section{Appendix A}

Table A1. Excess particulate biogenic $\mathrm{Ba}\left(\mathrm{Ba}_{\mathrm{xs}} ; \mathrm{pM}\right)$ and particulate $\mathrm{Al}(\mathrm{nM})$ during KEOPS 2.

\begin{tabular}{|c|c|c|c|c|c|c|c|c|c|c|c|c|c|c|c|}
\hline \multicolumn{8}{|c|}{ Station $\mathrm{A} 3$} & \multicolumn{8}{|c|}{ Station RK2 } \\
\hline \multicolumn{4}{|c|}{ A3-1 CTD4 } & \multicolumn{4}{|c|}{ A3-2 CTD 107} & \multicolumn{4}{|c|}{ R-2 CTD17 } & \multicolumn{4}{|c|}{ R-2 CTD 20} \\
\hline $\begin{array}{c}\text { Niskin } \\
\text { no. }\end{array}$ & $\begin{array}{c}\text { Depth } \\
{[\mathrm{m}]}\end{array}$ & $\begin{array}{l}\mathrm{Ba}_{\mathrm{xs}} \\
{[\mathrm{pM}]}\end{array}$ & $\begin{array}{c}\mathrm{Al} \\
{[\mathrm{nM}]}\end{array}$ & Niskin & $\begin{array}{c}\text { Depth } \\
{[\mathrm{m}]}\end{array}$ & $\begin{array}{l}\mathrm{Ba}_{\mathrm{xs}} \\
{[\mathrm{pM}]}\end{array}$ & $\begin{array}{c}\mathrm{Al} \\
{[\mathrm{nM}]}\end{array}$ & Niskin & $\begin{array}{c}\text { Depth } \\
\text { [m] }\end{array}$ & $\begin{array}{l}B a_{x s} \\
{[\mathrm{pM}]}\end{array}$ & $\begin{array}{c}\mathrm{Al} \\
{[\mathrm{nM}]}\end{array}$ & Niskin & $\begin{array}{c}\text { Depth } \\
{[\mathrm{m}]}\end{array}$ & $\begin{array}{l}\mathrm{Ba}_{\mathrm{xs}} \\
{[\mathrm{pM}]}\end{array}$ & $\begin{array}{c}\mathrm{Al} \\
{[\mathrm{nM}]}\end{array}$ \\
\hline 23 & 11 & 224 & 35 & 23 & 11 & 122 & 16 & 24 & 21 & 110 & 107 & 17 & 356 & 546 & 12 \\
\hline 21 & 42 & 217 & 64 & 21 & 40 & 140 & 12 & 23 & 40 & 0 & 693 & 15 & 507 & 239 & 17 \\
\hline 19 & 104 & 345 & 65 & 19 & 81 & 141 & 10 & 22 & 80 & 95 & 49 & 13 & 609 & 226 & 7 \\
\hline 17 & 152 & 234 & 19 & 17 & 126 & 82 & 27 & 20 & 100 & 131 & 27 & 11 & 812 & 267 & 3 \\
\hline 15 & 173 & 244 & 19 & 15 & 151 & 119 & 14 & 18 & 126 & 168 & 5 & 10 & 1011 & 189 & 2 \\
\hline 13 & 204 & 333 & 17 & 13 & 176 & 199 & 9 & 16 & 151 & 205 & 4 & 8 & 1520 & 201 & 4 \\
\hline 11 & 227 & 235 & 8 & 11 & 202 & 186 & 14 & 14 & 203 & 334 & 3 & 6 & 1832 & 184 & 2 \\
\hline 9 & 253 & 315 & 6 & 9 & 277 & 323 & 24 & 13 & 253 & 616 & 6 & 1 & 2473 & 286 & 3 \\
\hline 7 & 279 & 480 & 8 & 7 & 303 & 359 & 32 & 12 & 304 & 834 & 16 & & & & \\
\hline 5 & 354 & 216 & 21 & 5 & 405 & 247 & 19 & 10 & 404 & 573 & 9 & & & & \\
\hline \multirow[t]{4}{*}{1} & 474 & 1108 & 155 & 1 & 513 & 1842 & 186 & 9 & 507 & 430 & 10 & & & & \\
\hline & & & & & & & & 7 & 608 & 367 & 4 & & & & \\
\hline & & & & & & & & 5 & 708 & 337 & 10 & & & & \\
\hline & & & & & & & & 1 & 911 & 368 & 13 & & & & \\
\hline \multicolumn{16}{|c|}{ Station E } \\
\hline & E-1 Cl & D 27 & & & E-1 C & D 30 & & & E-2 CT & D 43 & & & E-3 C1 & D 50 & \\
\hline Niskin & $\begin{array}{c}\text { Depth } \\
\text { [m] }\end{array}$ & $\begin{array}{l}\mathrm{Ba}_{\mathrm{xs}} \\
{[\mathrm{pM}]}\end{array}$ & $\begin{array}{c}\mathrm{Al} \\
{[\mathrm{nM}]}\end{array}$ & Niskin & $\begin{array}{c}\text { Depth } \\
\text { [m] }\end{array}$ & $\begin{array}{l}B a_{x s} \\
{[\mathrm{pM}]} \\
\end{array}$ & $\begin{array}{c}\mathrm{Al} \\
{[\mathrm{nM}]}\end{array}$ & Niskin & $\begin{array}{c}\text { Depth } \\
\text { [m] }\end{array}$ & $\begin{array}{l}B a_{x s} \\
{[\mathrm{pM}]}\end{array}$ & $\begin{array}{c}\mathrm{Al} \\
{[\mathrm{nM}]}\end{array}$ & Niskin & $\begin{array}{c}\text { Depth } \\
\text { [m] }\end{array}$ & $\begin{array}{l}\mathrm{Ba}_{\mathrm{xs}} \\
{[\mathrm{pM}]}\end{array}$ & $\begin{array}{c}\mathrm{Al} \\
{[\mathrm{nM}]}\end{array}$ \\
\hline 24 & 21 & 896 & 166 & 17 & 303 & 424 & 30 & 23 & 11 & 192 & 43 & 24 & 11 & 129 & 45 \\
\hline 23 & 41 & 221 & 131 & 16 & 353 & 195 & 25 & 21 & 41 & 93 & 152 & 23 & 42 & 117 & 93 \\
\hline 22 & 81 & 190 & 161 & 15 & 455 & 143 & 6 & 18 & 102 & 143 & 17 & 22 & 71 & 130 & 28 \\
\hline 20 & 101 & 172 & 102 & 13 & 505 & 268 & 6 & 16 & 153 & 215 & 57 & 20 & 102 & 160 & 22 \\
\hline 18 & 125 & 150 & 10 & 11 & 636 & 343 & 7 & 14 & 204 & 408 & 9 & 18 & 125 & 201 & 11 \\
\hline 16 & 151 & 290 & 9 & 10 & 808 & 138 & 2 & 12 & 254 & 311 & 6 & 16 & 153 & 225 & 18 \\
\hline 14 & 182 & 375 & 5 & 8 & 1011 & 442 & 4 & 10 & 305 & 227 & 4 & 14 & 203 & 193 & 3 \\
\hline 13 & 253 & 450 & 12 & 6 & 1498 & 436 & 9 & 8 & 406 & 353 & 5 & 13 & 252 & 210 & 2 \\
\hline 12 & 303 & 402 & 9 & 1 & 2042 & 326 & 7 & 7 & 507 & 371 & 9 & 12 & 304 & 309 & 6 \\
\hline 10 & 403 & 327 & 10 & & & & & 6 & 609 & 271 & 10 & 10 & 404 & 316 & 7 \\
\hline 9 & 505 & 230 & 6 & & & & & 5 & 813 & 297 & 14 & 9 & 505 & 419 & 64 \\
\hline 7 & 605 & 305 & 10 & & & & & 4 & 1016 & 350 & 35 & 7 & 606 & 320 & 14 \\
\hline 5 & 707 & 298 & 10 & & & & & 1 & 2020 & 302 & 11 & 5 & 707 & 193 & 12 \\
\hline 1 & 913 & 309 & 7 & & & & & & & & & 1 & 912 & 265 & 5 \\
\hline & E-3 Cl & D 55 & & & E-4W C & TD 81 & & & E-4W C & TD 87 & & & E-4E C & D 94 & \\
\hline Niskin & $\begin{array}{c}\text { Depth } \\
\text { [m] }\end{array}$ & $\begin{array}{l}\mathrm{Ba}_{\mathrm{xs}} \\
{[\mathrm{pM}]}\end{array}$ & $\begin{array}{c}\mathrm{Al} \\
{[\mathrm{nM}]}\end{array}$ & Niskin & $\begin{array}{c}\text { Depth } \\
\text { [m] }\end{array}$ & $\begin{array}{l}\mathrm{Ba}_{\mathrm{xs}} \\
{[\mathrm{pM}]}\end{array}$ & $\begin{array}{c}\mathrm{Al} \\
{[\mathrm{nM}]}\end{array}$ & Niskin & $\begin{array}{c}\text { Depth } \\
\text { [m] }\end{array}$ & $\begin{array}{l}\mathrm{Ba}_{\mathrm{xs}} \\
{[\mathrm{pM}]}\end{array}$ & $\begin{array}{c}\mathrm{Al} \\
{[\mathrm{nM}]}\end{array}$ & Niskin & $\begin{array}{c}\text { Depth } \\
{[\mathrm{m}]}\end{array}$ & $\begin{array}{l}\mathrm{Ba}_{\mathrm{xs}} \\
{[\mathrm{pM}]}\end{array}$ & $\begin{array}{c}\mathrm{Al} \\
{[\mathrm{nM}]}\end{array}$ \\
\hline 17 & 404 & 185 & 5 & 24 & 10 & 101 & 16 & 17 & 304 & 277 & 9 & 24 & 20 & 116 & 32 \\
\hline 16 & 455 & 272 & 5 & 23 & 41 & 134 & 17 & 16 & 354 & 350 & 10 & 23 & 51 & 260 & 11 \\
\hline 15 & 505 & 176 & 6 & 22 & 70 & 152 & 5 & 15 & 453 & 233 & 7 & 22 & 93 & 563 & 223 \\
\hline 13 & 605 & 378 & 5 & 20 & 94 & 86 & 18 & 13 & 606 & 182 & 9 & 20 & 103 & 170 & 5 \\
\hline 11 & 810 & 258 & 3 & 18 & 126 & 84 & 7 & 11 & 811 & 186 & 5 & 18 & 126 & 215 & 9 \\
\hline 10 & 910 & 172 & 2 & 16 & 153 & 193 & 8 & 10 & 910 & 187 & 7 & 16 & 152 & 210 & 6 \\
\hline 8 & 1012 & 184 & 3 & 14 & 203 & 312 & 4 & 8 & 1011 & 268 & 61 & 14 & 181 & 247 & 7 \\
\hline 6 & 1214 & 228 & 6 & 13 & 252 & 628 & 17 & 6 & 1214 & 249 & 29 & 13 & 253 & 547 & 4 \\
\hline 1 & 1908 & 237 & 9 & 12 & 304 & 488 & 12 & 1 & 1384 & 250 & 30 & 12 & 305 & 403 & 78 \\
\hline & & & & 10 & 406 & 594 & 11 & & & & & 10 & 404 & 408 & 26 \\
\hline & & & & 9 & 507 & 272 & 11 & & & & & 9 & 505 & 403 & 26 \\
\hline & & & & 7 & 607 & 418 & 12 & & & & & 7 & 606 & 298 & 13 \\
\hline & & & & 5 & 708 & 338 & 21 & & & & & 5 & 706 & 285 & 8 \\
\hline & & & & 1 & 909 & 294 & 14 & & & & & 1 & 912 & 245 & 65 \\
\hline & & & & & & & Station 1 & ontinued) & & & & & & & \\
\hline & E-4E C & CD 97 & & & E-5 CT & 113 & & & E-5 CT & 114 & & & & & \\
\hline Niskin & $\begin{array}{c}\text { Depth } \\
{[\mathrm{m}]}\end{array}$ & $\begin{array}{l}\mathrm{Ba}_{\mathrm{xs}} \\
{[\mathrm{pM}]}\end{array}$ & $\begin{array}{c}\mathrm{Al} \\
{[\mathrm{nM}]}\end{array}$ & Niskin & $\begin{array}{c}\text { Depth } \\
\text { [m] }\end{array}$ & $\begin{array}{l}\mathrm{Ba}_{\mathrm{xs}} \\
{[\mathrm{pM}]}\end{array}$ & $\begin{array}{c}\mathrm{Al} \\
{[\mathrm{nM}]}\end{array}$ & Niskin & $\begin{array}{c}\text { Depth } \\
\text { [m] }\end{array}$ & $\begin{array}{l}\mathrm{Ba} a_{x s} \\
{[\mathrm{pM}]}\end{array}$ & $\begin{array}{c}\mathrm{Al} \\
{[\mathrm{nM}]}\end{array}$ & & & & \\
\hline 21 & 404 & 199 & 2 & 10 & 911 & 111 & 3 & 24 & 11 & 210 & 5 & & & & \\
\hline 18 & 505 & 242 & 3 & 8 & 1011 & 266 & 16 & 23 & 41 & 196 & 14 & & & & \\
\hline 13 & 706 & 175 & 1 & 6 & 1214 & 256 & 15 & 22 & 82 & 245 & 4 & & & & \\
\hline 8 & 1012 & 212 & 11 & 1 & 1922 & 208 & 5 & 20 & 102 & 264 & 14 & & & & \\
\hline 7 & 1265 & 189 & 2 & & & & & 18 & 126 & 131 & 6 & & & & \\
\hline 6 & 1518 & 149 & 2 & & & & & 16 & 152 & 153 & 5 & & & & \\
\hline 5 & 1827 & 225 & 43 & & & & & 14 & 202 & 181 & 2 & & & & \\
\hline 4 & 2027 & 212 & 12 & & & & & 13 & 252 & 469 & 6 & & & & \\
\hline 1 & 2212 & 254 & 9 & & & & & 12 & 302 & 606 & 9 & & & & \\
\hline & & & & & & & & 10 & 404 & 377 & 13 & & & & \\
\hline & & & & & & & & 9 & 507 & 422 & 11 & & & & \\
\hline & & & & & & & & 7 & 606 & 425 & 7 & & & & \\
\hline & & & & & & & & 5 & 707 & 281 & 12 & & & & \\
\hline & & & & & & & & 1 & 910 & 281 & 6 & & & & \\
\hline
\end{tabular}


Table A1. Continued.

\begin{tabular}{|c|c|c|c|c|c|c|c|c|c|c|c|c|c|c|c|}
\hline \multicolumn{8}{|c|}{ West-east transect } & \multicolumn{8}{|c|}{ Station F-L } \\
\hline \multicolumn{4}{|c|}{ TEW-3 CTD38 } & \multicolumn{4}{|c|}{ TEW-8 CTD 47} & \multicolumn{4}{|c|}{ F-L CTD 63} & \multicolumn{4}{|c|}{ F-L CTD 68} \\
\hline Niskin & $\begin{array}{c}\text { Depth } \\
{[\mathrm{m}]}\end{array}$ & $\begin{array}{l}\mathrm{Ba}_{\mathrm{xs}} \\
{[\mathrm{pM}]}\end{array}$ & $\begin{array}{c}\mathrm{Al} \\
{[\mathrm{nM}]}\end{array}$ & Niskin & $\begin{array}{c}\text { Depth } \\
{[\mathrm{m}]}\end{array}$ & $\begin{array}{l}\mathrm{Ba}_{\mathrm{xs}} \\
{[\mathrm{pM}]}\end{array}$ & $\begin{array}{c}\mathrm{Al} \\
{[\mathrm{nM}]}\end{array}$ & Niskin & $\begin{array}{c}\text { Depth } \\
{[\mathrm{m}]}\end{array}$ & $\begin{array}{l}\mathrm{Ba}_{\mathrm{xs}} \\
{[\mathrm{pM}]}\end{array}$ & $\begin{array}{c}\mathrm{Al} \\
{[\mathrm{nM}]}\end{array}$ & Niskin & $\begin{array}{c}\text { Depth } \\
{[\mathrm{m}]}\end{array}$ & $\begin{array}{l}\mathrm{Ba}_{\mathrm{xs}} \\
{[\mathrm{pM}]}\end{array}$ & $\begin{array}{c}\mathrm{Al} \\
{[\mathrm{nM}]}\end{array}$ \\
\hline 23 & 16 & 133 & 40 & 23 & 10 & 196 & 31 & 24 & 11 & 146 & 37 & 17 & 405 & 264 & 6 \\
\hline 21 & 41 & 107 & 112 & 21 & 41 & 0 & 251 & 23 & 35 & 97 & 41 & 16 & 456 & 233 & 9 \\
\hline 19 & 61 & 209 & 45 & 18 & 102 & 92 & 41 & 22 & 61 & 0 & 228 & 15 & 506 & 339 & 12 \\
\hline 17 & 76 & 148 & 20 & 16 & 152 & 169 & 45 & 20 & 82 & 141 & 36 & 13 & 607 & 265 & 3 \\
\hline 13 & 112 & 128 & 13 & 14 & 202 & 134 & 9 & 18 & 101 & 134 & 5 & 11 & 910 & 718 & 7 \\
\hline 11 & 183 & 235 & 8 & 12 & 254 & 164 & 5 & 16 & 126 & 185 & 5 & 10 & 1013 & 257 & 5 \\
\hline 9 & 253 & 391 & 11 & 10 & 304 & 268 & 12 & 14 & 151 & 221 & 5 & 8 & 1215 & 316 & 8 \\
\hline 7 & 277 & 348 & 9 & 8 & 405 & 217 & 5 & 13 & 202 & 280 & 7 & 6 & 1772 & 225 & 7 \\
\hline 5 & 404 & 356 & 8 & 7 & 507 & 319 & 5 & 12 & 252 & 399 & 8 & 1 & 2741 & 2999 & 131 \\
\hline \multirow[t]{5}{*}{1} & 545 & 242 & 13 & 6 & 609 & 209 & 8 & 10 & 303 & 420 & 7 & & & & \\
\hline & & & & 5 & 809 & 330 & 14 & 9 & 404 & 305 & 26 & & & & \\
\hline & & & & 4 & 1011 & 334 & 22 & 7 & 506 & 408 & 7 & & & & \\
\hline & & & & 1 & 2812 & 11179 & 826 & 5 & 707 & 247 & 10 & & & & \\
\hline & & & & & & & & 1 & 911 & 282 & 11 & & & & \\
\hline \multicolumn{12}{|c|}{ North-south transect } & & & & \\
\hline \multicolumn{4}{|c|}{ TNS-1 CTD15 } & \multicolumn{4}{|c|}{ TNS-6 CTD 10} & \multicolumn{4}{|c|}{ TNS-8 CTD8 } & & & & \\
\hline Niskin & $\begin{array}{c}\text { Depth } \\
\text { [m] }\end{array}$ & $\begin{array}{l}\mathrm{Ba}_{\mathrm{xs}} \\
{[\mathrm{pM}]}\end{array}$ & $\begin{array}{c}\mathrm{Al} \\
{[\mathrm{nM}]}\end{array}$ & Niskin & $\begin{array}{c}\text { Depth } \\
{[\mathrm{m}]}\end{array}$ & $\begin{array}{l}\mathrm{Ba}_{\mathrm{xs}} \\
{[\mathrm{pM}]}\end{array}$ & $\begin{array}{c}\mathrm{Al} \\
{[\mathrm{nM}]}\end{array}$ & Niskin & $\begin{array}{c}\text { Depth } \\
{[\mathrm{m}]}\end{array}$ & $\begin{array}{l}\mathrm{Ba}_{\mathrm{xs}} \\
{[\mathrm{pM}]}\end{array}$ & $\begin{array}{c}\mathrm{Al} \\
{[\mathrm{nM}]}\end{array}$ & & & & \\
\hline 23 & 11 & 262 & 62 & 23 & 35 & 182 & 26 & 23 & 12 & 478 & 45 & & & & \\
\hline 21 & 41 & 30 & 90 & 21 & 42 & 141 & 12 & 21 & 41 & 258 & 53 & & & & \\
\hline 18 & 102 & 93 & 15 & 18 & 103 & 143 & 14 & 18 & 102 & 303 & 32 & & & & \\
\hline 16 & 153 & 225 & 17 & 16 & 184 & 413 & 11 & 16 & 150 & 1008 & 33 & & & & \\
\hline 14 & 202 & 289 & 5 & 14 & 204 & 461 & 8 & 14 & 205 & 341 & 10 & & & & \\
\hline 12 & 253 & 228 & 2 & 12 & 255 & 298 & 5 & 12 & 254 & 447 & 6 & & & & \\
\hline 10 & 304 & 521 & 4 & 10 & 306 & 505 & 7 & 10 & 305 & 481 & 4 & & & & \\
\hline 8 & 405 & 346 & 3 & 8 & 407 & 474 & 4 & 8 & 405 & 312 & 3 & & & & \\
\hline 7 & 506 & 230 & 1 & 7 & 509 & 464 & 9 & 7 & 505 & 208 & 3 & & & & \\
\hline 6 & 607 & 352 & 13 & 6 & 610 & 315 & 15 & 6 & 606 & 283 & 7 & & & & \\
\hline 5 & 809 & 234 & 4 & 5 & 813 & 269 & 9 & 5 & 707 & 325 & 11 & & & & \\
\hline 4 & 1520 & 127 & 6 & 4 & 1526 & 362 & 13 & 4 & 910 & 376 & 35 & & & & \\
\hline 1 & 2282 & 211 & 19 & 1 & 1886 & 410 & 21 & 1 & 1000 & 294 & 28 & & & & \\
\hline
\end{tabular}


Acknowledgements. We thank the officers and crew of $\mathrm{R} / \mathrm{V}$ Marion Dufresne for their assistance during our work at sea. We are indebted to chief scientist S. Blain and voyage leader B. Quéguiner for their skillful leadership during the cruise and to the CTD team for managing rosette operation and CTD data. This research was supported by a French National Research Agency grant (project KEOPS 2, no. ANR-10-BLAN-0614), the Belgian Science Policy (BELSPO) project BIGSOUTH (SD/CA/05A), Flanders Research Foundation (FWO Project G071512N), the European Union Seventh Framework Programme (Marie Curie CIG MuSiCC, under grant agreement no. 294146 to D. Cardinal) and the Strategic Research Programme at Vrije Universiteit Brussel.

Edited by: S. Blain

\section{References}

Armand, L. K., Crosta, X., Quéguiner, B., Mosseri, J., and Garcia, N.: Diatoms preserved in surface sediments of the northeastern Kerguelen Plateau, Deep- Sea Res. Pt. II, 55, 677-692, 2008.

Blain, S., Tréguer, P., Belviso, S., Bucciarelli, E., Denis, M., Desabre, S., Fiala, M., Martin Jézéquel, V., Le Fèvre, J., Mayzaud, P., Marty, J.-C., and Razouls, S.: A biogeochemical study of the island mass effect in the context of the iron hypothesis: Kerguelen Islands, Southern Ocean, Deep-Sea Res. Pt. I, 48, 163-187, 2001.

Blain, S., Queguiner, B., Armand, L., Belviso, S., Bombled, B., Bopp, L., Bowie, A., Brunet, C., Brussaard, C., Carlotti, F., Christaki, U., Corbiere, A., Durand, I., Ebersbach, F., Fuda, J. -L., Garcia, N., Gerringa, L., Griffiths, B., Guigue, C., Guillerm, C., Jacquet, S., Jeandel, C., Laan, P., Lefevre, D., Lo Monaco, C., Malits, A., Mosseri, J., Obernosterer, I., Park, Y. -H., Picheral, M., Pondaven, P., Remenyi, T., Sandroni, V., Sarthou, G., Savoye, N., Scouarnec, L., Souhaut, M., Thuiller, D., Timmermans, K., Trull, T., Uitz, J., van Beek, P., Veldhuis, M., Vincent, D., Viollier, E., Vong, L., and Wagener, T.: Effect of natural iron fertilization on carbon sequestration in the Southern Ocean, Nature, 446, 1070-1074, 2007.

Blain, S., Quéguiner, B., and Trull, T.: The natural iron fertilization experiment keops (kerguelen ocean and plateau compared study): An overview, Deep-Sea Res. Pt. II, 55, 559-565, 2008.

Boyd, P. W., Watson, A. J., Law, C. S., Abraham, E. R., Trull, T., Murdoch, R., Bakker, D. C. E., Bowie, A. R., Buesseler, K. O., Chang, H., Charette, M., Croot, P., Downing, K., Frew, R., Gall, M., Hadfield, M., Hall, J., Harvey, M., Jameson, G., LaRoche, J., Liddicoat, M., Ling, R., Maldonado, M. T., McKay, R. M., Nobber, S., Pickmere, S., Pridmore, R., Rintoul, S., Safi, K., Sutton, P., Strzepek, R., Tanneberger, K., Turner, S., Waite, A., and Zeldis, J.: Phytoplankton bloom upon mesoscale iron fertilization of polar Southern Ocean water, Nature, 407, 695-702, 2000.

Boyd, P. W., Law, C. S., Wong, C. S., Nojiri, Y., Tsuda, A., Levasseur, M., Takeda, S., Rivkin, R., Harrison, P. J., Strzepek, R., Gower, J., McKay, R. M., Abraham, E., Arychuk, M., BarwellClarke, J., Crawford, W., Crawford, D., Hale, M., Harada, K., Johnson, K., Kiyosawa, H., Kudo, I., Marchetti, A., Miller, W., Needoba, J., Nishioka, J., Ogawa, H., Page, J., Robert, M., Saito, H., Sastri, A., Sherry, N., Soutar, T., Sutherland, N., Taira, Y., Whitney, F., Wong, S. K. E., and Yoshimura, T.: The decline and fate of an iron-induced subarctic phytoplankton bloom, Nature, 428, 549-553, 2004.

Boyd, P. W., Bakker, D. C. E., and Chandler, C.: A new database to explore the findings from large-scale ocean iron enrichments experiments, Oceanography, 25, 64-71, doi:10.5670/oceanog.2012.104, 2012.

Bowie, A. R., van der Merwe, P., Quéroué, F., Trull, T., Fourquez, M., Planchon, F., Sarthou, G., Chever, F., Townsend, A. T., Obernosterer, I., Sallée, J.-B., and Blain, S.: Iron budgets for three distinct biogeochemical sites around the Kerguelen archipelago (Southern Ocean) during the natural fertilisation experiment KEOPS-2, Biogeosciences Discuss., 11, 17861-17923, doi:10.5194/bgd-11-17861-2014, 2014.

Broecker, W. S., Takahashi, T., and Takahashi, T.: Sources and flow patterns of deep-ocean waters as deduced from potential temperature, salinity and initial phosphate concentration, J. Geophys. Res., 90, 6925-6939, 1985.

Buesseler, K. O. and Boyd, P. W.: Shedding light on processes that control particle export and flux attenuation in the twilight zone, Limnol. Oceanogr., 54, 1210-1232, 2009.

Buesseler, K. O., Andrews, J. E., Pike, S. M., and Charette, M. A.: The effect of iron fertilization on carbon sequestration in the Southern Ocean, Science, 304, 414-417, 2004.

Buesseler, K. O., Andrews, J. E., Pike, S. M., Charette, M. A., Goldson, L. E., Brzezinski, M. A., and Lance, V. P.: Particle export during the Southern Ocean Iron Experiment (SOFeX), Limnol. Oceanogr., 50, 311-327, 2005.

Buesseler, K. O., Antia, A. N., Chen, M., Fowler, S. W., Gardner, W. D., Gustaffson, Ö., Harada, K., Michaels, A. F., Rutgers van der Loeff, M., Sarin, M., Steinberg, D. K., and Trull, T.: An assessment of the use of sediment traps for estimating upper ocean particle fluxes, J. Mar. Res., 65, 345-416, 2007a.

Buesseler, K. O., Lamborg, C. H., Boyd, P. W., Lam, P. J., Trull, T. W., Bidigare, R. R., Bishop, J. K. B., Casciotti, K. L., Dehairs, F. , Elskens, M., Honda, M. , Karl, D. M., Siegel, D. A., Silver, M. W., Steinberg, D. K. , Valdes, J., Van Mooy, B., and Wilson, S.: Revisiting carbon flux through the ocean's twilight zone, Science, 316, 567-569, 2007b.

Cardinal, D., Dehairs, F., Cattaldo, T., and André, L.: Constraints on export and advection in the Subantarctic and Polar Front Zones, south of Australia from the geochemistry of suspended particles, J. Geophys. Res.-Oceans, 106, 31637-31656, 2001

Cardinal, D., Savoye, N., Trull., T.W., André, L., Kopczynska, E., and Dehairs, F.:, Particulate Ba distributions and fluxes suggest latitudinal variations of carbon mineralization in the Southern ocean, Deep-Sea Res. Pt. I, 52, 355-370, 2005.

Carlotti, F., Jouandet, M.-P., Nowaczyk, A., Harmelin-Vivien, M., Lefèvre, D., Guillou, G., Zhu, Y., and Zhou, M.: Mesozooplankton structure and functioning during the onset of the Kerguelen Bloom during Keops2 survey, Iogeosci. Iscuss., 12, 2381-2427, 2015.

Cavagna, A. J., Fripiat, F., Elskens, M., Dehairs, F., Mangion, P., Chirurgien, L., Closset, I., Lasbleiz, M., Flores-Leiva, L., Cardinal, D., Leblanc, K., Fernandez, C., Lefèvre, D., Oriol, L., Blain, S., and Quéguiner, B.: Biological productivity regime and associated $\mathrm{N}$ cycling in the vicinity of Kerguelen Island area, Southern Ocean, Biogeosciences Discuss., 11, 18073-18104, doi:10.5194/bgd-11-18073-2014, 2014. 
Closset, I., Lasbleiz, M., Leblanc, K., Quéguiner, B., Cavagna, A.J., Elskens, M., Navez, J., and Cardinal, D.: Seasonal evo- lution of net and regenerated silica production around a natu- ral Fefertilized area in the Southern Ocean estimated from Si isotopic approaches, Biogeosciences, 11, 5827-5846, doi:10.5194/bg-115827-2014, 2014.

Christaki, U., Obernosterer, I., VanWambeke, F., Veldhuis, M., Garcia, N., and Catala, P.: Microbial food web structure in a naturally iron fertilized area in the southern ocean (Kerguelen plateau), Deep-Sea Res. Pt. II, 55, 706-719, 2008.

Christaki, U., Lefèvre, D., Geoges, C., Colombet, J., catala, P., Courties, C., Sime-Ngando, T., Blain, S., and Obernosterer, I.: Microbial food web dynamics during spring phytoplankton blooms in the naturally iron-fertilized Kerguelen area (Southern Ocean), Biogeosciences, 11, 6739-3753, doi:10.5194/bg-116739-2014, 2014.

de Baar, H. J. W., Boyd, P. W., Coale, K. H., Landry, M. R., Tsud, A., Assmy, P., Bakker, D. C. E, Bozec, Y., Barber, R. T., Brzezinski, M. A., Buesseler, K. O., Boyé, M., Croot, P. L., Gervais, F., Gorbunov, Y., Harrison, P. J., Hiscock, W. T., Laan, P., Lancelot, C., Law, C. S., Levasseur, M., Marchetti, A., Millero, F. J., Nishika, J., Nojiri, Y., van Oijen, T., Riebesell, U., Rijkenberg, M. J. A., Saito, H., Takeda, S., Timmermans, K. R., Veldhuis, J. W., Waite, A. M., and Wong, C. S.: Synthesis of iron fertilization experiments: From the iron age in the age of enlightenment, J. Geophys. Res., 110, C09S16, doi:10.1029/2004JC002601, 2005.

Dehairs, F., Chesselet, R., and Jedwab, J.: Discrete suspended particles of barite and the barium cycle in the open ocean, Earth Planet. Sc. Lett., 49, 40-42, 1980.

Dehairs, F., Baeyens, W., and Goeyens, L.: Accumulation of suspended barite at mesopelagic depths and export production in the Southern Ocean, Science, 258, 1332-1335, 1992.

Dehairs, F., Shopova, D., Ober, S., Veth, C., and Goeyens, L.: Particulate barium stocks and oxygen consumption in the Southern Ocean mesopelagic water column during spring and early summer: Relationship with export production, Deep-Sea Res. Pt. II, 44, 497-516, 1997.

Dehairs, F., Jacquet, S. H. M., Savoye, N., van Mooy, B., Buesseler, K., Bishop, J., Lamborg, C., Elskens, M., Baeyens, W., Casciotti K., and Monnin, C.: Barium in twilight zone suspended matter as proxy for organic carbon mineralization: results for the North Pacific, Deep-Sea Res. Pt. II, 55, 1673-1683, 2008.

Dehairs, F., Fripiat, F., Cavagna, A.-J., Trull, T. W., Fernandez, C., Davies, D., Roukaerts, A., Fonseca Batista, D., Planchon, F., and Elskens, M.: Nitrogen cycling in the Southern Ocean Kerguelen Plateau area: evidence for significant surface nitrification from nitrate isotopic compositions, Biogeosciences Discuss., 11, 13905-13955, doi:10.5194/bgd-11-13905-2014, 2014.

D’Ovidio, F., Della Penna, A., Trull, T. W., Nencioli, F., Pujol, I., Rio, M. H., Park, Y. H., Cotté, C., Zhou, M., and Blain, S.: The biogeochemical structuring role of horizontal stirring: Lagrangian perspectives on iron delivery downstream of the Kerguelen plateau, Biogeosciences Discuss., 12, 779-814, doi:10.5194/bdg-12-779-2015, 2015.

Dymond, J. R., Suess, E., and Lyle, M.: Barium in deep-sea sediment: a geochemical proxy for paleoproductivity, Paleoceanography, 7, 163-181, 1992.

Ellison, Eurachem/CITAC Guide CG4, Quantifying Uncertainty in Analytical Measurement, edited by: Ellison, S.L.R., Rosslein,
M., and Williams, A., Second edition ISBN 094892615 5, 120 pp., 2000.

François, R., Honjo, S., Krishfield, R., and Manganini, S.: Factors controlling the flux of organic carbon to the bathypelagic zone of the ocean, Global Biogeochem. Cy., 16, 1087, doi:10.1029/2001GB001722, 2002.

Gervais, F., Riebesell, U., and Gorbunov, M. Y.: Changes in primary productivity and chlorophyll a in response to iron fertilization in the southern Polar Frontal Zone, Limnol. Oceanogr., 47, 13241335, 2002.

Henson, S., Sanders, R., Madsen, E., Morris, P., Le Moigne, F., and Quartly, G.: A reduced estimate of the strength of the ocean's biological carbon pump, Geophys. Res. Lett., 38, L04606, 2011.

Hoffmann, L., Peeken, I., Lochte, K., Assmy, P., and Veldhuis, M.: Different reactions of Southern Ocean phytoplankton size classes to iron fertilization, Limnol. Oceanogr, 51, 1217-1229, 2006.

Jacquet, S. H. M., Dehairs, F., Cardinal, D., Navez, J., and Delille, B.: Barium distribution across the Southern Ocean Frontal system in the Crozet-Kerguelen Basin, Mar. Chem., 95, 149-162, 2005.

Jacquet, S. H. M., Dehairs, F., Elskens, M., Savoye, N., and Cardinal, D.: Barium cycling along WOCE SR3 line in the Southern Ocean, Mar. Chem., 106, 33-45, 2007.

Jacquet, S. H. M., Dehairs, F., Savoye, N., Obernosterer, I., Christaki, U., Monnin, C., and Cardinal, D.: Mesopelagic organic carbon mineralization in the Kerguelen Plateau region tracked by biogenic particulate Ba, Deep-Sea Res. Pt. II, 55, 868-879, 2008a.

Jacquet, S. H. M., Savoye, N Dehairs, F., Strass, V., and Cardinal, D.: Mesopelagic carbon mineralization during the European Iron Fertilization Experiment (EIFEX), Glob. Biogeochem. Cy., 22, GB1023, doi:10.1029/2006GB002902, 2008b.

Jacquet, S. H. M., Dehairs, F., Becquevort, S., Dumont, I., Cavagna, A., and Cardinal, D.: Twilight zone organic carbon remineralization in the PFZ and SAZ south of Tasmania (Southern Ocean), Deep-Sea Res. Pt. II, 58, 2222-2234 doi:10.1016/j.dsr2.2011.05.029, 2011a.

Jacquet, S. H. M., Lam, P., Trull ,T., and Dehairs, F.: Carbon export production in the Polar front zone and Subantarctic Zone south of Tasmania, Deep-Sea Res. Pt. II, 58, 2277-2292, 2011 b.

Jouandet, M. P., Jackson, G. A., Carlotti, F., Picheral, M., Stemmann, L., and Blain, S.: Rapide formation of large aggregates during the spring bloom of Kerguelen Island: observation and model comparisons, Biogeosciences, 11, 4393-4406, doi:10.5194/bg-11-4393-2014, 2014 .

Lam, P. J. and Bishop, J. K. B.: High biomass, low export regimes in the Southern Ocean, Deep-Sea Res. Pt. II, 54, 601-638, 2007.

Lampitt, R. S. and Antia, A. N.: Particle flux in deep seas: regional characteristics and temporal variability, Deep-Sea Res. Pt. I, 44, 1377-1403, 1997.

Lampitt, R. S., Achterberg, E. P., Anderson, T. R., Hughes, J. A., Iglesisas-Rodriguez, M. D., Kelly-Gerreyn, B. A., Lucas, M., Popova, E. E., Sanders, R., Shepherd, J. G., Smythe-Wright, D., and Yool, A.: Ocean fertilization: A potential means of geoengineering?, Philos. Trans. R. Soc. A, 366, 3919-3945, 2008.

Lasbleiz, M., Leblanc, K., Blain, S., Ras, J., Cornet-Barthaux, V., Hélias Nunige, S., and Quéguiner, B.: Pigments, elemental composition $(\mathrm{C}, \mathrm{N}, \mathrm{P}$, and $\mathrm{Si}$ ), and stoichiometry of particulate matter in the naturally iron fertilized region of Kerguelen in the South- 
ern Ocean, Biogeosciences, 11, 5931-5955, doi:10.5194/bg-115931-2014, 2014.

Laurenceau-Cornec, E. C., Trull, T. W., Davies, D. M., Bray, S. G., Doran, J., Planchon, F., Carlotti, F., Jouandet, M.-P., Cavagna, A.-J., Waite, A. M., and Blain, S.: The relative importance of phytoplankton aggregates and zooplankton fecal pellets to carbon export: insights from free-drifting sediment trap deployments in naturally iron-fertilised waters near the Kerguelen plateau, Biogeosciences, 12, 1007-1027, doi:10.5194/bg-121007-2015, 2015.

Laws, E. A., Falkowski, P. G., Smith, W. O., Ducklow, H., and McCarthy, J. J.: Temperature effects on export production the ocean, Global Biogeochem. Cy., 14, 1231-1246, 2000.

Lefèvre, D., Guigue, C., and Obernosterer, I.: The metabolic balance at two contrasting sites in the Southern Ocean: the ironfertilized Kerguelen area and HNLC waters, Deep-Sea Res. Pt. II, 55, 766-776, 2008.

Le Moigne, F. A. C., Moore, C. M., Sanders, R. J., Villa-Alfageme, M., Steigenberger, S., and Achterberg, E. P.: Sequestration efficiency in the iron-limited North Atlantic: Implications for iron supply mode to fertilized blooms, Geophys. Res. Lett., 41, 46194627, doi:10.1002/2014GL060308, 2014.

Longhurst, A. R., Bedo, A. W., Harrison, W. G., Head, E. J. H., and Sameoto, D. D.: Vertical flux of respiratory carbon by oceanic diel migrant biota, Deep-Sea Res, 37, 685-694, 1990.

Maiti, K., Charette, M., Buesseler, K., and Kahru, M.: An inverse relationship between production and export efficiency in the Southern Ocean, Geophys. Res. Lett., 40, 1-5, 2013.

Martin, J. H., Knauer, G. A., Karl, D. M., and Broenkow, W. W.: VERTEX: carbon cycling in the NE Pacific, Deep-Sea Res., 34, 267-285, 1987.

Monnin, C., Jeandel, C., Cattaldo, T., and Dehairs, F.: The marine barite saturation state of the world's oceans, Mar. Chem., 65, 253-261, 1999.

Morris, P. J. and Charette, M. A.: A synthesis of upper oceancarbon and dissolved iron budgets for Southern Ocean natural iron fertilization studies, Deep-Sea Res., 90, 147-157, 2013.

Mosseri, J., Quéguiner, B., Armand, L. K., and Cornet-Barthaux, V.: Impact of iron on silicon utilization by diatoms in the Southern Ocean: a case study of $\mathrm{Si} / \mathrm{N}$ cycle decoupling in a naturally ironenriched area, Deep-Sea Res. Pt. II, 55, 801-819, 2008.

Park, Y.-H., Roquet, F., Durand, I., and Fuda, J.-L.: Large-scale circulation over and around the Northern Kerguelen Plateau, DeepSea Res. Pt. II, 55, 566-581, 2008.

Park, Y. H., Durand, I., Kestenare, E., Rougier, G., Zhou, M., d'Ovidio, F., Cotté, C., and Lee J. H.: Polar front around the Kerguelen islands: An up-to-date determination and associated circulation of surface/subsurface water, J. Geophys. Res. Oc., 119, 6575-6592, doi:10.1002/2014JC010061, 2014.

Passow, U. and Carlson, C. A.: The biological pump in a high $\mathrm{CO}_{2}$ world, Mar. Ecol. Prog. Ser., 470, 249-271, 2012.

Planchon, F., Cavagna A. J., Cardinal, D., André, L., and Dehairs, F.: Late summer particulate organic carbon export and twilight zone remineralisation in the Atlantic sector of the Southern Ocean, Biogeosciences, 10, 803-820, doi:10.5194/bg-10-8032013, 2013.

Planchon, F., Ballas, D., Cavagna A. J., Van Der Merwe, P., Bowie, A., Trull, T., Laurenceau-Cornec, E., Davis, D., and Dehairs, F.: Carbon export in the naturally iron fertilized Kergue- len area of the Southern Ocean using 234Th-based approach, Biogeosciences Discuss., 11, 15991-16032, doi:10.5194/bgd11-15991-2014, 2014.

Porris, P. J., Sanders, R., Turnewithsch, R., and Thomalla, S.: $234^{T h}$-derived particulate organic carbon export from an islandinduced phytoplankton blomm in the Southern Ocean,Deep-Sea Res. Pt. II, 24, 2208-2232, 2007.

Quéroué, F., Sarthou, G., Planquette, H. F., Bucciarelli, E., Chever, F., van der Merwe, P., Lannuzel, D., Townsend, A. T., Cheize, M., Blain, S., d'Ovidio, F., and Bowie, A. R.: High variability of dissolved iron concentrations in the vicinity of Kerguelen Island (Southern Ocean), Biogeosciences Discuss., 12, 231270, doi:10.5194/bgd-12-231-2015, 2015.

Rembauville, M., Blain, S., Armand, L., Quéguiner, B., and Salter, I.: Export fluxes in a naturally fertilized area of the Southern Ocean, the Kerguelen Plateau: ecological vectors of carbon and biogenic silica to depth (Part 2), Biogeosciences Discuss., 11, 17089-17150, doi:10.5194/bgd-11-17089-2014, 2014.

Robinson, J., Popova, E. E., Yool, A., Srokosz, M. A., Lampitt, R. S., and Blundell, J. R.: How deep is deep enough? Ocean iron fertilization and carbon sequestration in the Southern Ocean, Geophys. Res. Lett., 41, 2489-2495, 2014.

Salter, I., Lampitt, R. S., Sanders, R., Poulton, A., Kemp, A. E. S., Boorman, B., Saw, K., and Pearce, R.: Estimating carbon, silica and diatom export from a naturally fertilised phytoplankton bloom in the Southern Ocean using PELAGRA: a novel drifting sediment trap, Deep-Sea Res. Pt. II, 54, 2233-2259, 2007.

Sarmiento, J. L., Slater, R. D., Fasham, M. J. R., Ducklow, H. W., and Toggweiler, J. R.: A seasonal three-dimensional ecosystem model of nitrogen cycling in the North Atlantic photic zone, Global Biogeochem. Cy., 7, 417-450, 1993.

Savoye, N., Trull, T., Jacquet, S. H. M., Navez, J., and Dehairs, F.: ${ }^{234}$ Th-derived export fluxes during a natural iron fertilization experiment (KEOPS), Deep-Sea Res. Pt. II, 55, 841-855, 2008.

Schlitzer, R.: Ocean Data View, http://www.awi-bremerhaven.de/ GEO/ODV, 2002.

Schneider, B., Bopp, L., and Gehlen, M.: Assessing the sensitivity of modeled airsea $\mathrm{CO} 2$ exchange to the remineralization depth of particulate organic and inorganic carbon, Global Biogeochem. Cy., 22, GB3021, doi:10.1029/2007GB003100, 2008.

Shopova, D., Dehairs, F., and Baeyens, W.: A simple model of biogeochemical element distribution in the oceanic water column, J. Mar. Sy., 6, 331-344, 1995.

Smetacek, V., Klass, C., Strass, V. H., Assmy, P., Montresor, M., Cisewki, B., Savoye, N., Webb, A., d'Ovidio, F., Arrieta, J. M., Bathmann, U., Bellerby, R., Mine Berg, G., Croot, P., Gonzalez, S., Jenjes, J., Herndl, G. J., Hoffmann, L.J., Leach, H., Losh, M., Mills, M. M., Neill, C., Peeken, I., Rottgers, R., Sachs, O., Sauter, E., Schmidt, M. M., Schwarz, J., Terbruggen, A., and Wolf-Gladrow, D.: Deep carbon export from a Southern Ocean iron-fertilized diatom bloom, Nature, 487, 313-319, 2012.

Sternberg, E., Jeandel, C., Miquel, J.-C., Gasser, B., Souhaut, M., Arraes-Mescoff, R., and Francois R.: Particulate barium fluxes and export production in the northwestern Mediterranean, Mar. Chem. 105, 281-295, 2007.

Sternberg, E., Jeandel, C., Robin, E., and Souhaut, M.: Seasonal cycle of suspended barite in the Mediterranean Sea, Geochim. Cosmochim. Ac., 72, 4020-4034, 2008a. 
Sternberg, E., Tang, D., Ho, T. Y., Jeandel, C., and Morel, M. M..: Barium uptake and adsorption in diatoms, Geochim. Cosmochim. Ac., 69, 2745-2752, 2008b.

Strass, V., Cisewski, B., Gonzales, S., Leach, H., Loquay, K.-D., Prandke, H., Rohr, H., and Thomas, M.: The physical setting of the European Iron Fertilization Experiment "EIFEX" in the Southern Ocean, Reports Pol. Mar. Res., 500, 15-49, 2005.

Stroobants, N., Dehairs, F., Goeyens, L., Vanderheijden, N., and Van Grieken, R.: Barite formation in the Southern Ocean water column, Mar. Chem., 35, 411-422, 1991.

Taylor, S. R. and McLennan, S. M.: The continental crust: its composition and evolution, Blackwell Scientif. Publicat., 312 pp., 1985.

van der Merwe, P., Bowie, A. R., Quéroué, F., Armand, L., Blain, S., Chever, F., Davies, D., Dehairs, F., Planchon, F., Sarthou, G., Townsend, A. T., and Trull, T.: Sourcing the iron in the naturallyfertilised bloom around the Kerguelen Plateau: particulate trace metal dynamics, Biogeosciences, 12, 739-755, doi:10.5194/bg12-739-2015, 2015.
Venchiarutti, C., Jeandel, C., and Roy-Barman, M.: Particle dynamics study in the wake of Kerguelen Island using thorium isotopes, Deep-Sea Res. Pt. I, 55, 1343-1363, 2008.

Williams, P. J. and Jenkinson, N. W.: A transportable microprocessor-controlled precise Winkler titration suitable for field station and shipboard use, Limnol. Oceanogr., 27, 576-585, 1982.

Zhou, M., Zhu, Y., Dorland, R. D., and Measures, C. I.: Dynamics of the current system in the southern Drake Passage, Deep-Sea Res. Pt. I, 57, 1039-1048, 2010.

Zhou, M., Zhu, Y., Measures, C. I., Hatta, M., Charette, M. A., Gille, S. T., Frants, M., Jiang, M., and Mitchell, B. G.: Winter mesoscale circulation on the shelf slope region of the southern Drake Passage, Deep-Sea Res. Pt. II, 90, 4-14, 2013. 